\title{
Ground-based aerosol characterization during the South American Biomass Burning Analysis (SAMBBA) field experiment
}

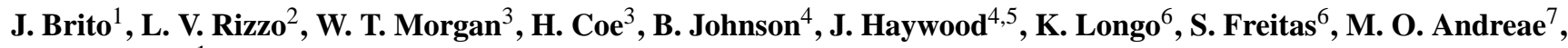 \\ and P. Artaxo ${ }^{1}$ \\ ${ }^{1}$ Physics Institute, University of São Paulo, São Paulo, Brazil \\ ${ }^{2}$ Department of Earth and Exact Sciences, Federal University of São Paulo, Diadema, Brazil \\ ${ }^{3}$ Centre of Atmospheric Sciences, School of Earth, Atmospheric and Environmental Science, \\ University of Manchester, Manchester, UK \\ ${ }^{4}$ UK Met Office, Exeter, UK \\ ${ }^{5}$ College of Engineering, Maths and Physical Science, University of Exeter, Exeter, UK \\ ${ }^{6}$ National Institute for Space Research (INPE), São José dos Campos, Brazil \\ ${ }^{7}$ Biogeochemistry Department, Max Planck Institute for Chemistry, Mainz, Germany
}

Correspondence to: J. Brito (jbrito@if.usp.br)

Received: 23 April 2014 - Published in Atmos. Chem. Phys. Discuss.: 14 May 2014

Revised: 30 September 2014 - Accepted: 1 October 2014 - Published: 18 November 2014

\begin{abstract}
This paper investigates the physical and chemical characteristics of aerosols at ground level at a site heavily impacted by biomass burning. The site is located near Porto Velho, Rondônia, in the southwestern part of the Brazilian Amazon rainforest, and was selected for the deployment of a large suite of instruments, among them an Aerosol Chemical Speciation Monitor. Our measurements were made during the South American Biomass Burning Analysis (SAMBBA) field experiment, which consisted of a combination of aircraft and ground-based measurements over Brazil, aimed to investigate the impacts of biomass burning emissions on climate, air quality, and numerical weather prediction over South America. The campaign took place during the dry season and the transition to the wet season in September/October 2012.

During most of the campaign, the site was impacted by regional biomass burning pollution (average $\mathrm{CO}$ mixing ratio of $0.6 \mathrm{ppm}$ ), occasionally superimposed by intense (up to 2 ppm of $\mathrm{CO}$ ), freshly emitted biomass burning plumes. Aerosol number concentrations ranged from $\sim 1000 \mathrm{~cm}^{-3}$ to peaks of up to $35000 \mathrm{~cm}^{-3}$ (during biomass burning (BB) events, corresponding to an average submicron mass mean concentrations of $13.7 \mu \mathrm{g} \mathrm{m}^{-3}$ and peak concentrations close to $100 \mu \mathrm{g} \mathrm{m}^{-3}$. Organic aerosol strongly dominated the submicron non-refractory composition, with an average concen-
\end{abstract}

tration of $11.4 \mathrm{\mu g} \mathrm{m}^{-3}$. The inorganic species, $\mathrm{NH}_{4}, \mathrm{SO}_{4}$, $\mathrm{NO}_{3}$, and $\mathrm{Cl}$, were observed, on average, at concentrations of $0.44,0.34,0.19$, and $0.01 \mu \mathrm{g} \mathrm{m}^{-3}$, respectively. Equivalent black carbon $\left(\mathrm{BC}_{\mathrm{e}}\right)$ ranged from 0.2 to $5.5 \mu \mathrm{g} \mathrm{m}^{-3}$, with an average concentration of $1.3 \mathrm{\mu g} \mathrm{m}^{-3}$. During BB peaks, organics accounted for over $90 \%$ of total mass (submicron non-refractory plus $\mathrm{BC}_{\mathrm{e}}$ ), among the highest values described in the literature.

We examined the ageing of biomass burning organic aerosol (BBOA) using the changes in the $\mathrm{H}: \mathrm{C}$ and $\mathrm{O}: \mathrm{C}$ ratios, and found that throughout most of the aerosol processing $(\mathrm{O}: \mathrm{C} \cong 0.25$ to $\mathrm{O}: \mathrm{C} \cong 0.6)$, no remarkable change is observed in the $\mathrm{H}: \mathrm{C}$ ratio $(\sim 1.35)$. Such a result contrasts strongly with previous observations of chemical ageing of both urban and Amazonian biogenic aerosols. At higher levels of processing $(\mathrm{O}: \mathrm{C}>0.6)$, the $\mathrm{H}: \mathrm{C}$ ratio changes with a $\mathrm{H}: \mathrm{C} / \mathrm{O}: \mathrm{C}$ slope of -0.5 , possibly due to the development of a combination of $\mathrm{BB}(\mathrm{H}: \mathrm{C} / \mathrm{O}: \mathrm{C}$ slope $=$ $0)$ and biogenic $(\mathrm{H}: \mathrm{C} / \mathrm{O}: \mathrm{C}$ slope $=-1)$ organic aerosol (OA). An analysis of the $\triangle \mathrm{OA} / \triangle \mathrm{CO}$ mass ratios yields very little enhancement in the OA loading with atmospheric processing, consistent with previous observations. These results indicate that negligible secondary organic aerosol (SOA) formation occurs throughout the observed BB plume 
processing, or that SOA formation is almost entirely balanced by $\mathrm{OA}$ volatilization.

Positive matrix factorization (PMF) of the organic aerosol spectra resulted in three factors: fresh BBOA, aged BBOA, and low-volatility oxygenated organic aerosol (LV-OOA). Analysis of the diurnal patterns and correlation with external markers indicates that during the first part of the campaign, OA concentrations are impacted by local fire plumes with some chemical processing occurring in the near-surface layer. During the second part of the campaign, long-range transport of BB plumes above the surface layer, as well as potential SOAs formed aloft, dominates OA concentrations at our ground-based sampling site.

This manuscript describes the first ground-based deployment of the aerosol mass spectrometry at a site heavily impacted by biomass burning in the Amazon region, allowing a deeper understanding of aerosol life cycle in this important ecosystem.

\section{Introduction}

The Brazilian Amazon covers an area of 5.5 million $\mathrm{km}^{2}$ and holds about 100 billion metric tons of carbon (Malhi et al., 2008). This vast region includes both pristine and humanimpacted areas. In the central Amazon during the wet season, for example, aerosol median number concentrations of $220 \mathrm{~cm}^{-3}$ and mass concentrations of the order of $1.5 \mu \mathrm{g} \mathrm{m}^{-3}$ (diameter $<2 \mu \mathrm{m}$ ) have been observed (Pöschl et al., 2010; Artaxo et al., 2013), which are among the lowest found at any continental site and are similar to observations over remote oceans (Andreae, 2007). Conversely, mainly in the southern and western Amazon, human activities, especially biomass burning, significantly alter natural conditions (Andreae et al., 2004; Davidson et al., 2012; Sena et al., 2013; Artaxo et al., 2013). The expansion of agriculture, logging, and urban areas has considerably affected the Amazon Basin since the 1950s, and deforestation has eliminated about $17 \%$ of the original forest area (Ometto et al., 2005; Davidson et al., 2012). As an important part of the deforestation process, fire is being extensively used for the preparation of agricultural fields after a patch of forest has been cut down, for the conversion of croplands to pasture for cattle grazing, or for pasture maintenance. Given the high amount of precipitation in the region, ranchers cut down the forest at the end of the wet season (May-June), let the wood dry until September, and usually burn it by November.

A number of studies in the last few years have focused on the role of aerosol particles in cloud development and suppression in the Amazon (Andreae et al., 2004; Koren et al., 2004, 2005; Feingold et al., 2005; Lin et al., 2006; Zhang et al., 2009). These studies have shown that, given the combination of low cloud condensation nuclei (CCN) concentrations and high water vapor, the pristine Amazonian at- mosphere is very sensitive to aerosol concentration changes, with significant impacts on cloud development and invigoration. Furthermore, biomass burning plumes have been shown to decrease the amount of global photosynthetically available radiation at different canopy levels, affecting sensible and latent heat fluxes at the surface, and the net ecosystem exchange (Yamasoe et al., 2006; Oliveira et al., 2007; Doughty et al., 2010). It has been suggested, however, that the impact of this decrease in PAR on vegetation productivity may be offset to some degree by increases in diffuse PAR, which increases photosynthetic activity (e.g., Mercado et al., 2009). The effects of such fires have been observed over millions of square kilometers, covering large areas of South America, even far from the Amazon region (Artaxo et al., 1988; Andreae et al., 2001; Artaxo et al., 2002; Andreae et al., 2004; Freitas et al., 2005; Andreae et al., 2012).

The South American Biomass Burning Analysis (SAMBBA) is an international research project for the investigation of the impacts of biomass burning emissions on climate, air quality, and numerical weather prediction over South America. SAMBBA consists of a combination of measurements and modeling activities for assessing the role of biomass burning and biogenic emissions in the Earth System. The project involved a combination of aircraft measurements over Brazil, using the BAe-146 research aircraft from the Facility for Airborne Atmospheric Measurements (FAAM), along with ground-based measurements near Porto Velho, Rondônia. The campaign took place during the dry season and the transition to the wet season in September/October 2012. This manuscript focuses on the ground-based measurements.

Several instruments were deployed at the ground-based sampling site, including trace gas monitors and instrumentation for the physical and chemical characterization of aerosol, among them an Aerosol Chemical Speciation Monitor (ACSM, Aerodyne Research Inc.). The ACSM is a compact version of the widely used Aerosol Mass Spectrometer (AMS, Aerodyne Research Inc.) (Jayne et al., 2000; Canagaratna et al., 2007). In the last decade, a number of studies have applied aerosol mass spectrometry for biomass burning aerosol characterization across a wide range of environments and burning materials (Capes et al., 2008; Aiken et al., 2010; Cubison et al., 2011; Lack et al., 2013, and references therein). However, Amazonian biomass burning aerosols were only recently, during SAMBBA, characterized using aerosol mass spectrometry. These measurements provide an interesting contrast to the results from the wet season in the central Amazon, during the Amazonian Aerosol Characterization Experiment 2008 (AMAZE-08), which reported during clean periods an average non-refractory submicron mass concentration of $0.6 \mu \mathrm{g} \mathrm{m}^{-3}, 91 \%$ organic and $7 \%$ sulfate, with an average oxygen-to-carbon $(\mathrm{O}: \mathrm{C})$ ratio of 0.42 (Chen et al., 2009). 


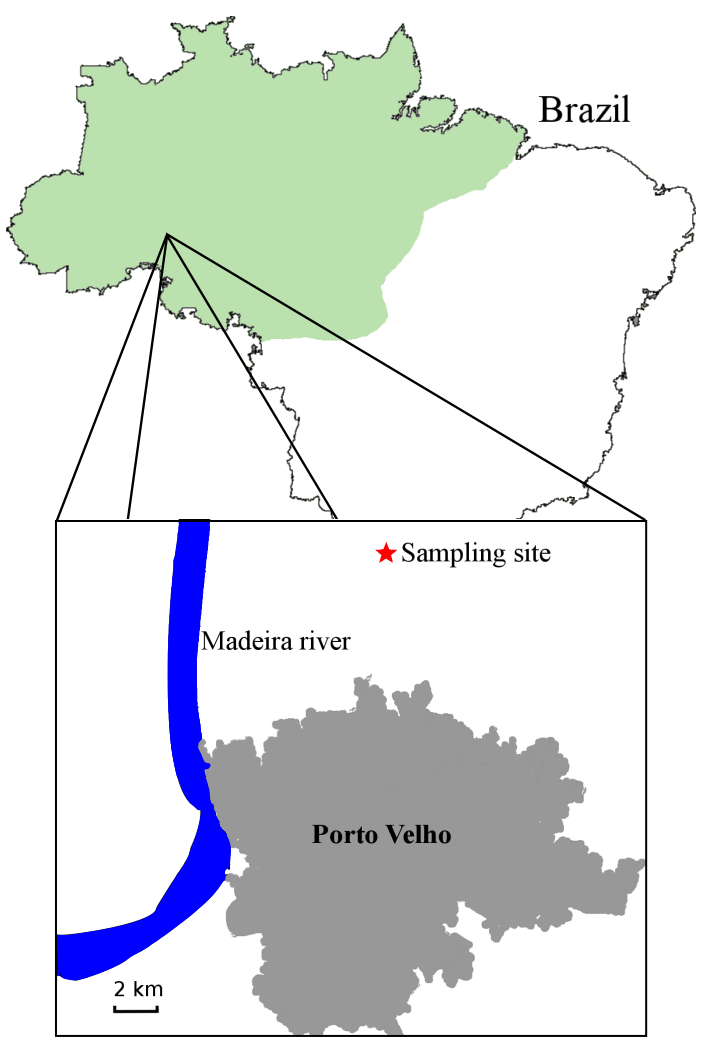

Figure 1. Map of Brazil indicating the Amazon region (in green) and detailed view of the city of Porto Velho and the sampling site.

Here, the changes in the atmospheric composition in an area subject to anthropogenic emissions in the western Amazon will be analyzed under the scope of aerosol mass spectrometry with the aim of better understanding the aerosol life cycle and its physical and chemical properties.

\section{Experimental}

The data reported here focus on the period from 13 to 30 September 2012, comprising the transition period from the dry to the wet season. In the following sections, a description of the site and instrumentation is provided.

\subsection{Site description}

The sampling site $\left(8.69^{\circ} \mathrm{S}, 63.87^{\circ} \mathrm{W}\right)$ is located about $5 \mathrm{~km}$ north (usually upwind) of Porto Velho, a city in the state of Rondônia with 485000 inhabitants (Fig. 1). The whole region has been subject to land use change since the 1980s. The instrumentation was housed in an air conditioned container placed on the border of a $150 \mathrm{~m}$ radius grassland clearance at the southwest corner of 2000 ha of dense forest belonging to a reservation. The road that connects Porto Velho to the reservation cuts through large pasture areas and a handful of local businesses. No vehicular access is permitted within the reservation.

Aerosol measurements were performed $5 \mathrm{~m}$ a.g.l., roughly $4 \mathrm{~m}$ away from dense forest. Diffusion dryers maintained sampled air under relatively dry conditions $(\mathrm{RH}<50 \%)$. An inlet with $50 \%$ aerodynamic cutoff at $2.5 \mu \mathrm{m}$ for our flow conditions was used for sampling.

\subsection{Instrumentation}

The aerosol size distribution in the range of $10-430 \mathrm{~nm}$ was measured using an SMPS (Scanning Mobility Particle Sizer, TSI, model 3936) composed of an electrostatic classifier (TSI, model 3080) along with a CPC (Condensation Particle Counter, TSI, model 3772). Coarse-mode particle number size distributions were measured using an OPC (Optical Particle Counter, Grimm, model 1.109). Carbon monoxide measurements were performed using a Picarro analyzer, model G2301. An Aethalometer (Magee Scientific, model AE30) provided equivalent black carbon $\left(\mathrm{BC}_{\mathrm{e}}\right)$ mass concentrations throughout the campaign, which was corrected for filter loading and multiple scattering effects according to Arnott et al. (2005) and Schmid et al. (2006) using aerosol light scattering measured using an Ecotech Aurora 3000 Nephelometer.

An Aerosol Chemical Speciation Monitor (ACSM) was used to provide realtime ( $30 \mathrm{~min}$ resolution) chemically resolved mass concentrations of particulate ammonium, nitrate, sulfate, chloride, and organic species in the submicron size range ( $\mathrm{Ng}$ et al., 2011b). The ACSM efficiently samples aerosol particles through an aerodynamic lens in the $75-650 \mathrm{~nm}$ size range. The focused particle beam is transmitted into a detection chamber where the non-refractory fraction is flash-vaporized on a hot surface (typically $600^{\circ} \mathrm{C}$ ). Subsequently, the evaporated gas-phase compounds are ionized by electron impact at $70 \mathrm{eV}$ and their spectrum obtained using a quadrupole mass spectrometer. The chemical speciation is determined via deconvolution of the mass spectra according to the method described by Allan et al. (2004). Due to the high concentration of organics relative to other species, especially when sampling strongly BB-impacted air masses, corrections to the instrument chemical assignment were performed (Bae et al., 2007; Akagi et al., 2012).

The mass calibration of the ACSM was performed at the beginning and at the end of the campaign, with less than $5 \%$ deviation in the obtained calibration factors. The calibration system consisted of an ultrasonic nebulizer used for primary aerosol generation, a silica gel diffusion dryer (custom made), an electrostatic classifier (TSI, model 3080), and a condensation particle counter (CPC, TSI, Model 3772). The system was used to generate known amounts of monodisperse $300 \mathrm{~nm}$ ammonium nitrate aerosol particles, as described by $\mathrm{Ng}$ et al. (2011b). The number concentration was varied by diluting the generated aerosol between approximately $10-1000 \mathrm{~cm}^{-3}$, which corresponds to a mass concentration of $0.15-15 \mu \mathrm{g} \mathrm{m}^{-3}$ for nitrate. 


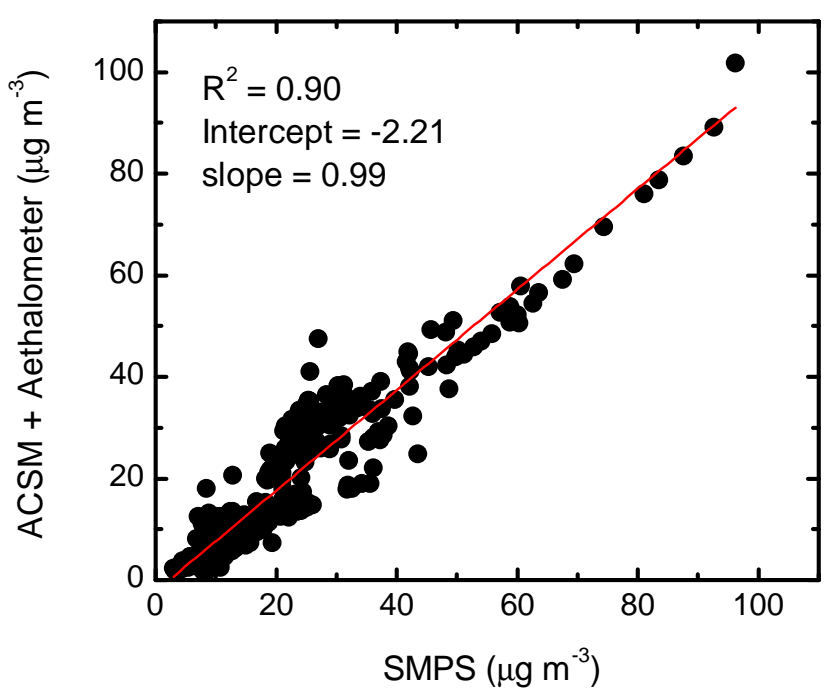

Figure 2. Comparison between the sum of the mass concentrations of species measured by the ACSM (assuming a CE of 1) and Aethalometer (at $880 \mathrm{~nm}$ ) vs. aerosol volume obtained from SMPS and time-dependent aerosol density.

The collection efficiency (CE) has been previously reported to range from 0.5 to 1 , depending on system setup and aerosol physical-chemical characteristics (Huffman et al., 2005; Canagaratna et al., 2007; Matthew et al., 2008; Middlebrook et al., 2012). Here, the CE was evaluated through the comparison of the mass concentration of species measured by the ACSM and Aethalometer $\left(\mathrm{BC}_{\mathrm{e}}\right.$, measured at $\left.880 \mathrm{~nm}\right)$ with the integrated mass of the SMPS (aerodynamic diameter upper limit of $620 \mathrm{~nm}$ ). The density used for each species was $1.78,1.72,1.72,1.52$, and $1.77 \mathrm{~g} \mathrm{~cm}^{-3}$ for sulfate, nitrate, ammonium, chloride, and BC, respectively (Lide, 1991; Park et al., 2004). The density of organics was estimated based on the oxygen-to-carbon $(\mathrm{O}: \mathrm{C})$ and hydrogen-to-carbon $(\mathrm{H}: \mathrm{C})$ ratios (Kuwata et al., 2012). The median aerosol density was calculated to be $1.48 \mathrm{~g} \mathrm{~cm}^{-3}$, which was $1.21 \mathrm{~g} \mathrm{~cm}^{-3}$ during the biomass burning peak. Results of intercomparison suggest that a CE of 1 provides the best fit for the data set presented here (Fig. 2). Such a CE is in good agreement with the results of Middlebrook et al. (2012), who suggested an increase in CE in environments dominated by organic aerosols

\section{Analysis tools}

Aerosol mass spectrometry uses several of the observed molecular masses to apportion aerosol species as well as different atmospheric processes. Among those, the most important are the two dominant oxygen containing ions in the spectra, $m / z 44$ (mostly $\mathrm{CO}_{2}^{+}$in ambient data) and $m / z$ 43. The $m / z 43$ fragment is mainly $\mathrm{C}_{2} \mathrm{H}_{3} \mathrm{O}^{+}$for the more processed aerosol, and $\mathrm{C}_{3} \mathrm{H}_{7}^{+}$for the freshly emitted, hydrogen-rich organic aerosol (OA). The ratio of $m / z 44$ to the total signal in the component spectrum (defined as $f_{44}$ ) and its relationship to $f_{43}$ (defined similarly) can be used as a metric for the level of atmospheric processing ( $\mathrm{Ng}$ et al., 2010; Morgan et al., 2010). Conversely, the signal at $m / z 60$, associated with the $\mathrm{C}_{2} \mathrm{H}_{4} \mathrm{O}^{+}$ion (Schneider et al., 2006; Alfarra et al., 2007), correlates extremely well with levoglucosan and similar anhydrosugar species (mannosan, galactosan) which arise from the pyrolysis of cellulose. Therefore, the ratio of the mass fragment at $m / z 60$ relative to the total OA signal, defined as $f_{60}$, is a widely used metric for biomass burning influence (Capes et al., 2008; Cubison et al., 2011).

The application of factor analysis to the AMS/ACSM data allows for the identification of several types of organic aerosol (OA). Normally OA is deconvolved mainly into hydrocarbon-like $\mathrm{OA}(\mathrm{HOA})$ and oxygenated $\mathrm{OA}(\mathrm{OOA})$, as well as other site-specific components (Lanz et al., 2007; Ulbrich et al., 2009; Ng et al., 2010; Carbone et al., 2013). HOA and OOA are under most conditions good surrogates for primary $\mathrm{OA}(\mathrm{POA})$ and secondary $\mathrm{OA}(\mathrm{SOA})$, respectively $(\mathrm{Ng}$ et al., 2010). OOA can be further deconvolved into semivolatile OOA (SV-OOA) and low volatility OOA (LV-OOA) (Jimenez et al., 2009). Further details on the used factor analysis, i.e., positive matrix factorization, are given in Sect. 3.1.

Besides OA deconvolution using factor analysis, an interesting approach for understanding OA atmospheric processing was proposed by Heald et al. (2010), via OA mapping in a van Krevelen diagram ( $\mathrm{H}: \mathrm{C}$ vs. $\mathrm{O}: \mathrm{C}$ ) (Van Krevelen, 1950). In this diagram, OA processing is represented by an increase in the $\mathrm{O}: \mathrm{C}$ ratio, and the slope of the ageing line (concurrent relative change in the $\mathrm{O}: \mathrm{C}$ and $\mathrm{H}: \mathrm{C}$ ratios) may help highlight the type of functional groups formed. The data obtained during AMAZE-08, for example, cluster along a line with slope of $\sim-1$, consistent with simultaneous increases in carbonyl and alcohol moieties, either at separate carbons or due to the addition of carboxylic acid groups (Heald et al., 2010). Focusing only on the OOA component, $\mathrm{Ng}$ et al. (2011a) identified that most processing occurred along a line of slope of $\sim-0.5$. Such a change in the $\mathrm{O}: \mathrm{C}$ and $\mathrm{H}: \mathrm{C}$ ratios would be consistent with several simple mechanisms, such as the net addition of both $\mathrm{COOH}$ and $\mathrm{OH} / \mathrm{OOH}$ functional groups without fragmentation (i.e., $\mathrm{C}-\mathrm{C}$ bond cleavage), and/or the addition of $\mathrm{COOH}$ groups with fragmentation.

\subsection{Positive matrix factorization}

Positive matrix factorization (PMF) is a statistical model that uses weighted least-square fitting for factor analysis (Paatero and Tapper, 1994; Paatero, 1997). It uses a bilinear model $\mathbf{X}=\mathbf{G F}+E$, where $\mathbf{X}$ is a matrix of the measured values, and $\mathbf{G}$ and $\mathbf{F}$ are matrices computed by the model that represent the scores and loading, respectively. For the ACSM (as well as AMS) data, each row in $\mathbf{X}$ is a mass spectrum measured at a given time, with the columns representing the signal at a given $m / z$. In this case, $\mathbf{G}$ represents the time series and $\mathbf{F}$ 

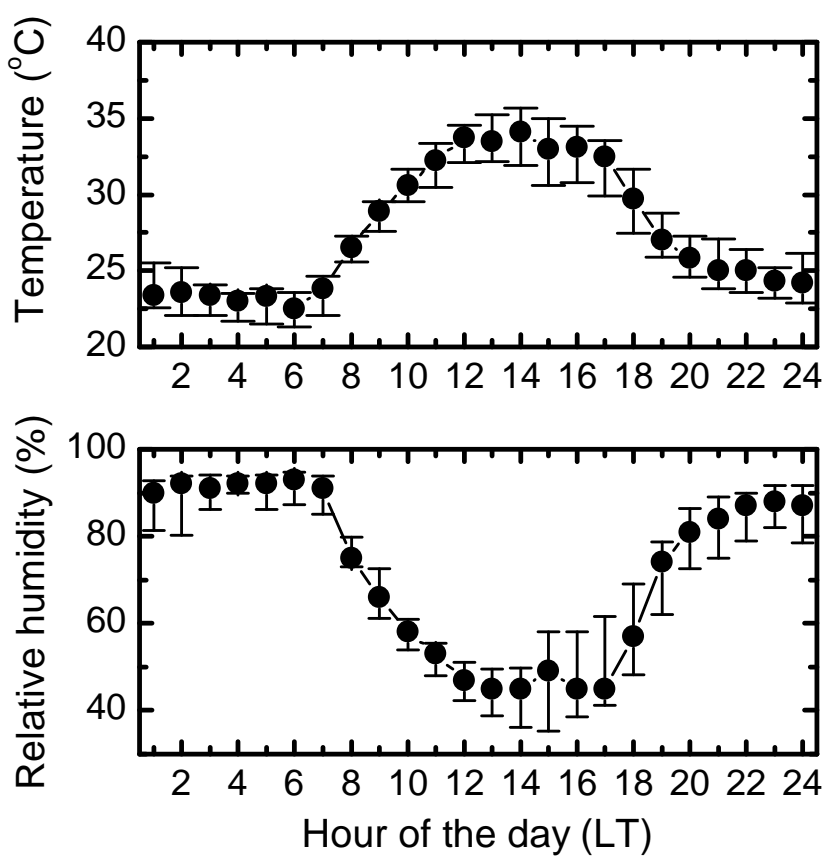

Figure 3. Diurnal variation of meteorological parameters during the SAMBBA campaign. The top plot indicates temperature and the bottom plot relative humidity. Circles represent median values, and bars represent 10 and 90 percentiles. Data from the National Institute of Meteorology.

the profile mass spectrum for the $p$ factors computed by the algorithm. $E$ is the difference between the measured signal and that reconstructed by the product of $\mathbf{G}$ and $\mathbf{F}$ and is made up of the elements $e_{i j}$. The model adjusts $\mathbf{G}$ and $\mathbf{F}$ in order to reduce the object function $(Q)$, where

$Q=\sum_{i=1}^{m} \sum_{j=1}^{n}\left(e_{i j} / \sigma_{i j}\right)^{2}$

and $\sigma_{i j}$ is the uncertainty for each element in the matrix $\mathbf{X}$. For AMS measurements in continental regions, where the sources of inorganic aerosol are well understood, PMF is typically only performed on the organic aerosol mass spectrum (e.g., Lanz et al., 2007; Ulbrich et al., 2009) in order to learn more about the sources and transformation processes of organic aerosol. The PMF2 program (Paatero, 1997) was used to analyze these data in robust mode with an outlier distance of 4 and no model error. The PMF evaluation tool kit (PET) (Ulbrich et al., 2009) was used to prepare the data and error estimates, execute PMF, and evaluate the results. Further details on the PMF analysis procedure can be found in the Supplement.

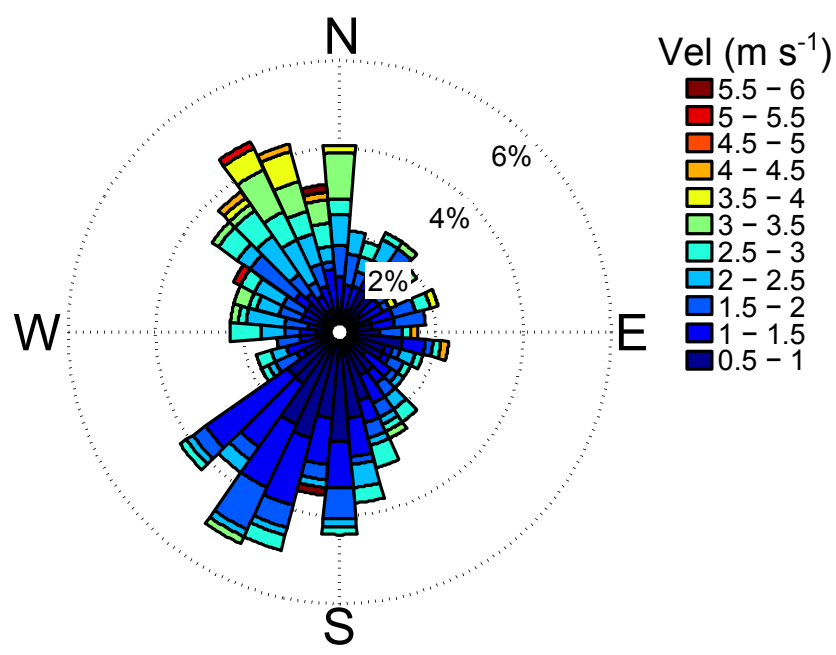

Figure 4. Wind rose from the sampling site during the SAMBBA campaign. Data from the National Institute of Meteorology.

\section{Results and discussion}

\subsection{Meteorology}

During the SAMBBA campaign, comprising the transition from dry to wet season, median values of temperature in Porto Velho ranged from $22^{\circ} \mathrm{C}$ (nighttime) to $35^{\circ} \mathrm{C}$ (around 14:00 LT) and relative humidity from $90 \%$ (nighttime) down to $40 \%$ (around 14:00 LT), as depicted in Fig. 3. Precipitation was scarce throughout the campaign, occurring mostly near the end. The wind rose is depicted in Fig. 4, indicating a dominant flow from the NW direction, considering wind direction frequency and intensity, with some important contributions from the SW direction. Possible aerosol sources associated with prevailing wind directions will be discussed in Sects. 4.3.

\subsection{Aerosol composition}

The time series of submicron non-refractory aerosol composition, $\mathrm{BC}_{\mathrm{e}}$ concentration, aerosol number concentration, average particle diameter, and $\mathrm{CO}$ mixing ratio are shown in Fig. 5. Organic aerosol strongly dominated the submicron non-refractory composition, with an average concentration of $11.4 \mathrm{\mu g} \mathrm{m}^{-3}$. The inorganic species, $\mathrm{NH}_{4}, \mathrm{SO}_{4}$, $\mathrm{NO}_{3}$, and $\mathrm{Cl}$, were observed, on average, at concentrations of $0.44 \mu \mathrm{g} \mathrm{m}^{-3}, 0.34 \mu \mathrm{g} \mathrm{m}^{-3}, 0.19 \mu \mathrm{g} \mathrm{m}^{-3}$, and $0.01 \mu \mathrm{g} \mathrm{m}^{-3}$, respectively. $\mathrm{BC}_{\mathrm{e}}$ was observed at an average concentration of $1.30 \mathrm{\mu g} \mathrm{m}^{-3}$. Aerosol number size distributions were mostly found in the accumulation mode (average size distribution of $94 \mathrm{~nm}$ ), with average particle number concentrations around $5700 \mathrm{~cm}^{-3}$. During most of the campaign, the site was impacted by regional biomass burning pollution (average $\mathrm{CO}$ mixing ratio of $0.6 \mathrm{ppm}$ ), occasionally superimposed by intense biomass burning plumes (up to $2 \mathrm{ppm}$ of $\mathrm{CO}$ ). These 
Table 1. Mean values observed during SAMBBA separated between Phase I (13 to 22 September 2012) and Phase II (22 to 30 September 2012). Non-refractory and $\mathrm{BC}_{\mathrm{e}}$ concentrations are given in $\mu \mathrm{g} \mathrm{m}^{-3}$. CO is given in ppmv, aerosol number concentration $(N)$ in 1000 particles $\mathrm{cm}^{-3}$, and aerosol mean diameter $\left(D_{\mathrm{pg}}\right)$ in $\mathrm{nm}$.

\begin{tabular}{lrr}
\hline Parameter & Phase I & Phase II \\
\hline Organics & 15.0 & 4.5 \\
$\mathrm{SO}_{4}$ & 0.38 & 0.27 \\
$\mathrm{NO}_{3}$ & 0.23 & 0.10 \\
$\mathrm{NH}_{4}$ & 0.6 & 0.3 \\
$\mathrm{Cl}$ & 0.01 & $\mathrm{ND}^{\mathrm{a}}$ \\
$\mathrm{BC}$ & 1.58 & 0.85 \\
$\mathrm{CO}$ & 0.67 & 0.40 \\
$N$ & 6.7 & 4.5 \\
$D_{\text {pg }}$ & 105 & 78 \\
\hline
\end{tabular}

a Below detection limit.

values can be considered typical for the late dry season in the southern Amazon, as can be seen from the close agreement with measurements made during the Smoke Aerosols, Clouds, Rainfall, and Climate 2002 (SMOCC-2002) campaign at a pasture site $285 \mathrm{~km}$ southeast of Porto Velho (Chand et al., 2006). $\mathrm{BC}_{\mathrm{e}}$ peaks that do not coincide with marked enhancements in non-refractory aerosols and $\mathrm{CO}$ are associated with brickyard emissions, discussed in the Supplement.

Given that SAMBBA took place during the end of the dry season and transition to the wet season, the campaign was separated into Phase I (13 to 22 September 2012) and Phase II (22 to 30 September 2012). The mean values observed during both phases of SAMBBA are presented in Table 1. The aerosol composition is shown to be significantly different during intense biomass burning events. Fig. 6 shows the correlation between fOrg (defined as the fraction of organics relative to the species detected by the ACSM plus $\mathrm{BC}_{\mathrm{e}}$ ) vs. $f_{60}$. The $f_{60}$ parameter provides a reliable marker for air masses impacted by fresh and relatively low-processed BB emissions (Cubison et al., 2011); a value of 0.003 is usually accepted as a reasonable threshold for BB-impacted air masses. Our results show that during strong impact of biomass burning $\left(f_{60}>0.015\right)$, fOrg was above 0.9 . This value is considerably higher than previous measurements at other locations, where fOrg of biomass burning plumes ranged from 0.85 to 0.60 (Artaxo et al., 2013). The large range of fOrg values observed for periods with $f_{60} \leq 0.01$ is attributed to occasional brickyard emissions affecting the sampling site, as discussed in the Supplement.

\subsubsection{Chemical ageing of the biomass burning organic aerosol}

As the sampling site was located in a region with intense fire activity, fire spots were distributed both near and far from the site. In this context, an analysis of changes in chemical composition throughout the campaign was carried out. An important method for the analysis of chemical processing is the van Krevelen (VK) diagram, i.e., a plot of the O : C vs. H : C ratios (Van Krevelen, 1950). Whereas high-resolution AMS allows direct measurement of the element ratios required for the VK diagram, the unit mass resolution of the ACSM requires these to be estimated. Based on the work of Aiken et al. (2008) and $\mathrm{Ng}$ et al. (2011a), the parameters $f_{44}$ and $f_{43}$ are used to obtain $\mathrm{O}: \mathrm{C}$ and $\mathrm{H}: \mathrm{C}$ ratios, respectively. The $f_{43}$ and $\mathrm{H}: \mathrm{C}$ relationship proposed by $\mathrm{Ng}$ et al. (2011a) is limited to OOA only, where $m / z 43$ is mainly linked to the $\mathrm{C}_{2} \mathrm{H}_{3} \mathrm{O}^{+}$fragment. Our results, despite including a strong biomass burning organic aerosol (BBOA) component, indicate an important OOA contribution ( $f_{44}$ is larger than 0.05 at all times). Similarly processed BBOA (DeCarlo et al., 2010) has shown an excellent agreement between the $\mathrm{H}: \mathrm{C}$ ratio estimated from $f_{43}$ and the directly observed $\mathrm{H}: \mathrm{C}$ ratio (Ng et al., 2011a).

The VK diagram of bulk OA measurements during the SAMBBA campaign is depicted in Fig. 7. During the most intense biomass burning plume $\left(f_{60}>0.03\right), \mathrm{H}: \mathrm{C}=1.35$ and $\mathrm{O}: \mathrm{C}=0.25$. In contrast, results from the characterization of biogenic aerosol in the Amazon region during AMAZE-08 (Heald et al., 2010) show a relatively higher $\mathrm{H}: \mathrm{C}$ ratio for the less oxidized particles $(\mathrm{H}: \mathrm{C}=1.6$ and $\mathrm{O}: \mathrm{C}=0.2$ ). As the $f_{60}$ marker decreases (indicating both well processed aerosol and OA from other sources), the observed $\mathrm{H}: \mathrm{C}$ and $\mathrm{O}: \mathrm{C}$ ratios tend to agree well with the processed biogenic aerosol $(\mathrm{H}: \mathrm{C}=1.2$ and $\mathrm{O}: \mathrm{C}=0.7)$ from AMAZE-08. This agreement can be attributed both to the fact that aerosols tend to become more chemically similar with increasing ageing, independent of the initial source of the material (Jimenez et al., 2009; Ng et al., 2010), and to the increasing importance of biogenic OA at the sampling site as the smoke becomes more dilute.

Biogenic organic aerosols have been observed to follow a clear processing path along a line with a $\mathrm{H}: \mathrm{C} / \mathrm{O}: \mathrm{C}$ slope of -1 in the VK plot (Heald et al., 2010), indicating that for each oxygen atom added upon oxidation, a hydrogen atom is lost. This change is consistent with equal increases in carbonyl and alcohol moieties, such as carboxylic acid addition. The biomass burning aerosol in Rondônia, however, shows a different behavior, with the majority of oxygen-to-carbon ratio change (from $\mathrm{O}: \mathrm{C} \cong 0.25$ to $\mathrm{O}: \mathrm{C} \cong 0.6$ ) accompanied by only a small change in the $\mathrm{H}: \mathrm{C}$ ratio. Such processing is consistent with the replacement of a hydrogen with an alcohol group (-OH), for example. For $\mathrm{O}: \mathrm{C}>0.6$, the average slope changes to -0.5 . Such a slope could arise from an increase in the importance of biogenic aerosol processing (slope $=-1$ ) relative to BBOA processing (slope $=0$ ) and/or a change in the dominating reaction.

As they were derived from an Unit Mass Resolution instrument, the atomic ratios presented here were not directly measured and thus contain substantial uncertainties compared 

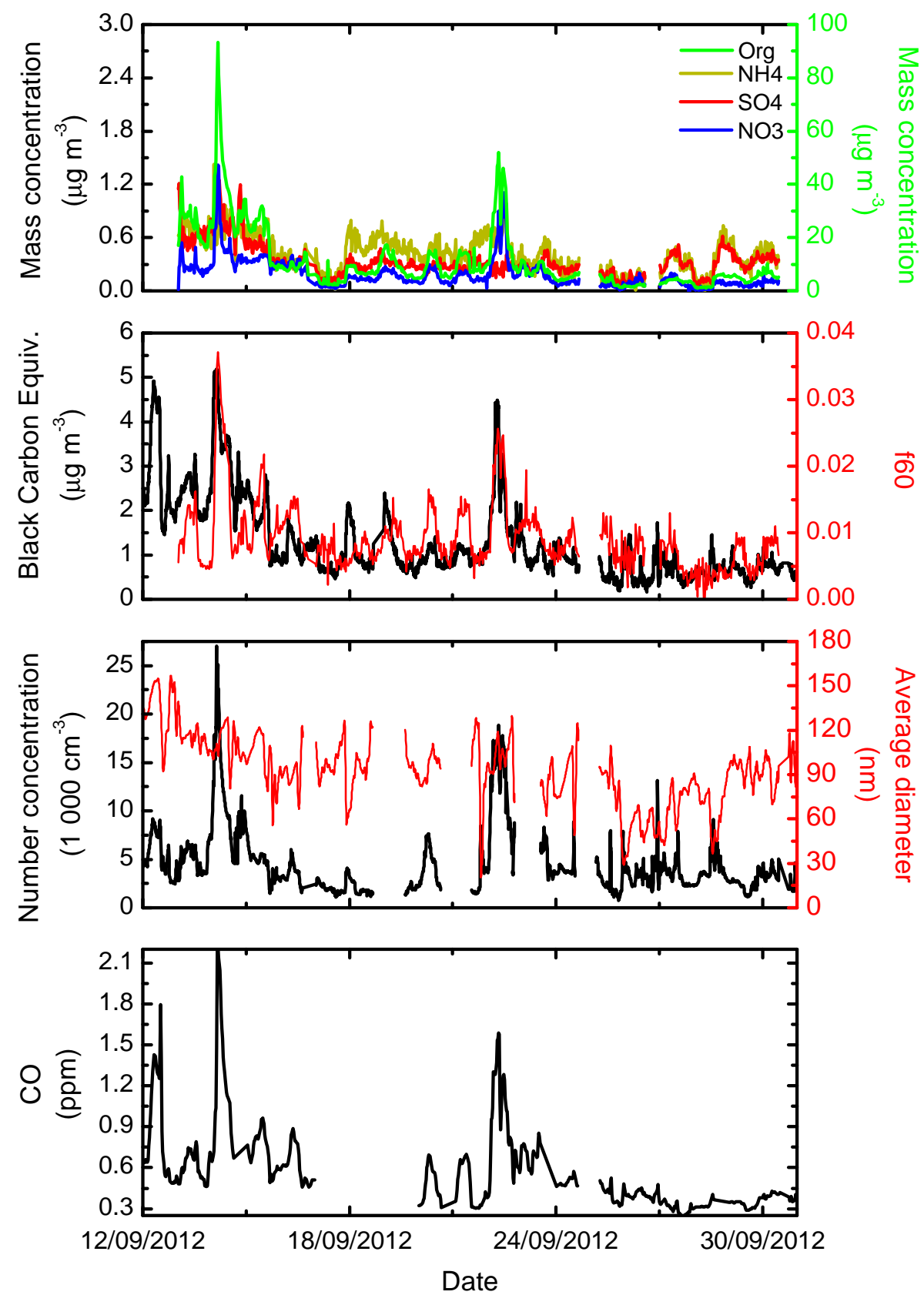

Figure 5. Concentration time series of organics, $\mathrm{SO}_{4}, \mathrm{NO}_{3}$ and $\mathrm{NH}_{4}(\mathbf{a}), \mathrm{BC}_{\mathrm{e}}$ and $f_{60}$ (b), particle number concentration and numberweighted average diameter (c), and $\mathrm{CO}$ mixing ratio (d).

to the references above. Considering a $10 \%$ standard deviation from the $\mathrm{f} 43$ to $\mathrm{H}$ : C relationship as described by $\mathrm{Ng}$ et al. (2011a) alone, the BBOA slope in the van Krevelen diagram, identified to be 0 , would range from -0.5 to 0.5 , considerably affecting the conclusions regarding BBOA chemical processing. Furthermore, recent results, currently under validation, suggest a significant underestimation of $\mathrm{O}: \mathrm{C}$ and $\mathrm{H}: \mathrm{C}$ ratios from HR-AMS measurements (Canagaratna et al., 2014). For the data set presented here, $\mathrm{O}: \mathrm{C}$ and $\mathrm{H}: \mathrm{C}$ were be underestimated by 11 and $24 \%$, respectively. Such a change, however, does not substantially impact the van Krevelen diagram, shown in the Supplement (Fig. S8). Even with these large uncertainties, the results shown here suggest a different processing path in the van Krevelen diagram than previously reported, and certainly justifies a better characterization of fast changes in the chemical processing of BBOA in the Amazon region 


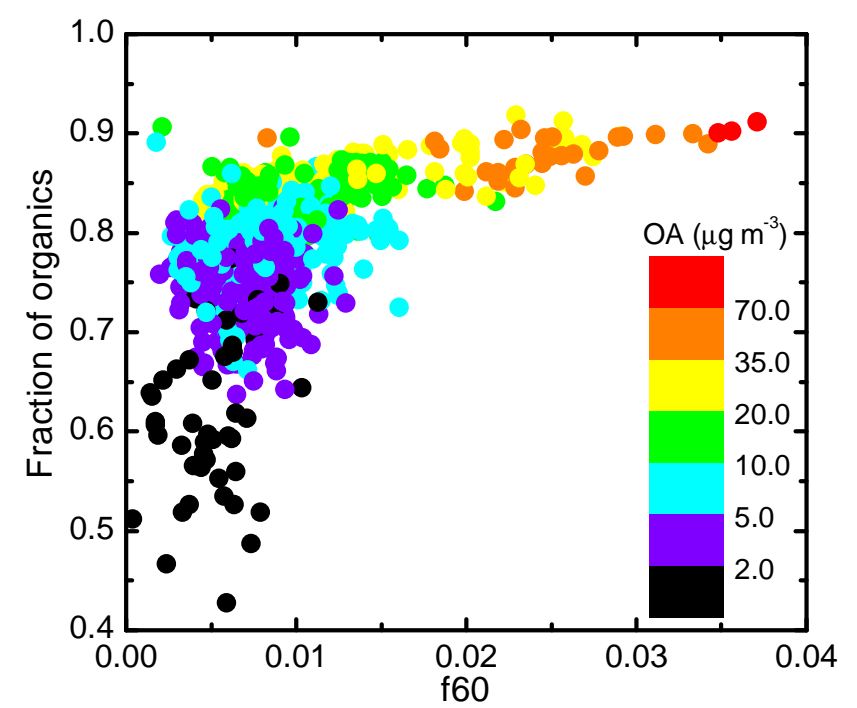

Figure 6. The fraction of organic aerosol relative to total mass (nonrefractory and $\mathrm{BC}_{\mathrm{e}}$ ) vs. $f_{60}$, a marker for $\mathrm{BB}$-impacted air masses.

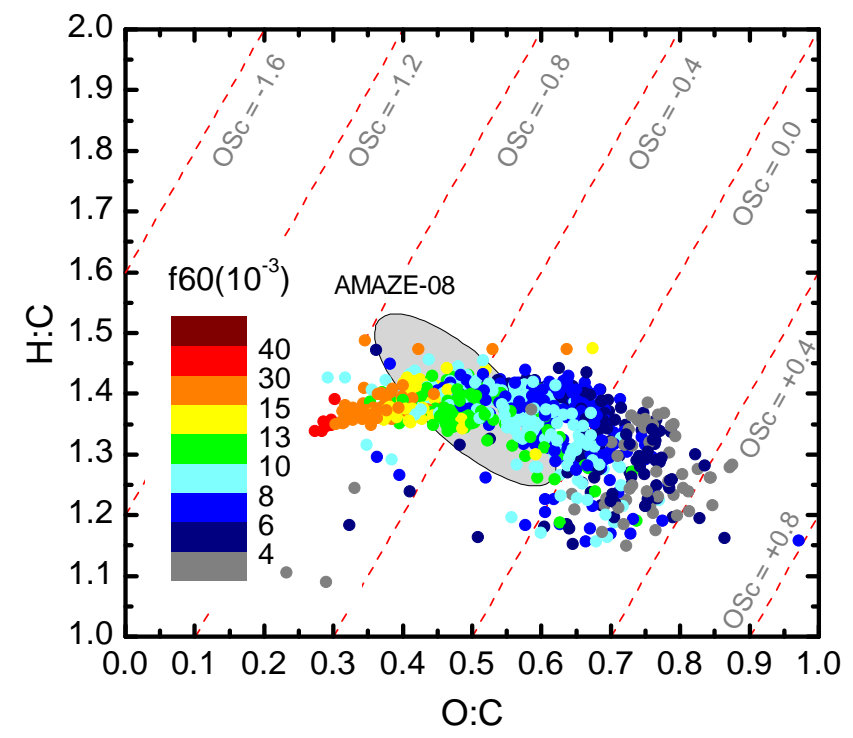

Figure 7. Representation of the OA components into the VK triangle diagram. The estimated carbon oxidation states $\left(\overline{\mathrm{OS}}_{\mathrm{C}} \approx 2 \times\right.$ $\mathrm{O} / \mathrm{C}-\mathrm{H} / \mathrm{C}$ ) are shown as red dotted lines. The gray area indicates the V-K space from AMAZE-08 as described by Heald et al. (2010).

The impact of plume ageing on SOA production has been studied previously. Recent laboratory measurements have shown significant SOA yields from oxidation of volatile products of biomass burning under low- $\mathrm{NO}_{\mathrm{x}}$ conditions (Yee et al., 2013). Ambient measurements, however, have produced conflicting results, ranging from net $\mathrm{OA}$ enhancement (DeCarlo et al., 2008; De Gouw and Jimenez, 2009) to no net OA production (Capes et al., 2008; Cubison et al., 2011) and even to a net OA decrease (Akagi et al., 2012; Jolleys et al., 2012).
Table 2. Parameters of the three log-normal fits shown in Fig. 9. The parameters $N_{i}, \sigma_{i}$ and $\bar{D}_{i}$ refer to mode number concentration, mean geometric diameter, and geometric standard deviation, respectively, for a given aerosol diameter $D$ as $\frac{N_{i}}{\sqrt{2 \pi} \log \sigma_{i}} e^{-\left(\log D-\log \bar{D}_{i}\right)^{2} / 2 \log \left(\sigma_{i}\right)^{2}}$.

\begin{tabular}{lrrr}
\hline Mode & $N_{i}$ & $\sigma_{i}$ & $\bar{D}_{i}$ \\
\hline Nucleation & 948 & 2.50 & 14.2 \\
Aitken & 4071 & 1.78 & 98.1 \\
Accumulation & 1063 & 1.48 & 179.1 \\
\hline
\end{tabular}

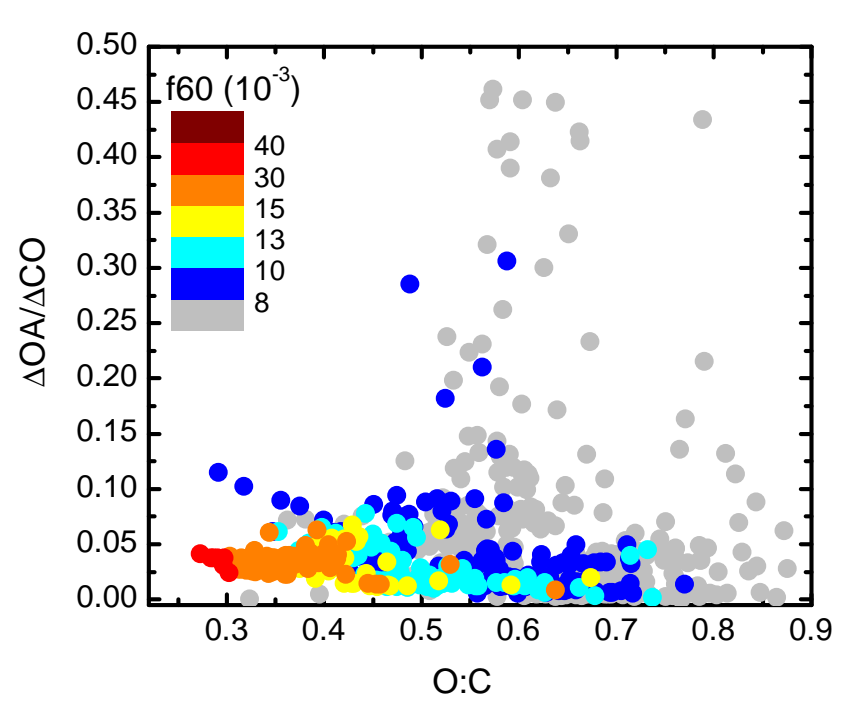

Figure 8. $\triangle \mathrm{OA} / \Delta \mathrm{CO}$ mass ratios vs. $\mathrm{O}: \mathrm{C}$ ratio.

Figure 8 depicts the $\triangle \mathrm{OA} / \triangle \mathrm{CO}$ mass ratio for a given $\mathrm{O}: \mathrm{C}$ ratio. For the calculation of $\Delta \mathrm{CO}$, we chose the lowest $\mathrm{CO}$ mixing ratio observed throughout the campaign, $240 \mathrm{ppb}$, as background. Phase-specific backgrounds were calculated as $290 \mathrm{ppb}$ and $240 \mathrm{ppb} \mathrm{ppb}$ for phase I and II, respectively, a difference less than $10 \%$ of average $\mathrm{CO}$ level, thus with little impact in $\triangle \mathrm{OA} / \triangle \mathrm{CO}$ mass ratios. Conversely, the lowest concentration of OA was only $0.2 \mu \mathrm{g} \mathrm{m}^{-3}$, thus we chose zero as background. High values of $\Delta \mathrm{OA} / \Delta \mathrm{CO}$, characteristic of biogenic air masses, are observed for $f_{60}<0.008$. The values in this range should be viewed with caution as they correspond to data with low $\triangle \mathrm{CO}$, and are thus subject to large uncertainty related to the $\mathrm{CO}$ background subtraction. This aside, $\triangle \mathrm{OA} / \triangle \mathrm{CO}$ is fairly constant around 0.03 , indicating no net $\mathrm{OA}$ production tendencies from biomass burning emissions.

\subsubsection{Aerosol size distribution}

A script was developed to fit one to three lognormal modes to the measured particle number size distributions in the range 10-430 nm, based on the approach of Hussein et al. (2005). Aitken $(\sim 30-120 \mathrm{~nm})$ and accumulation $(\sim 70-280 \mathrm{~nm})$ 
modes dominated the particle number concentration in $98 \%$ of the observed size spectra, with average concentrations of $2000 \pm 2300$ and $1500 \pm 1600 \mathrm{~cm}^{-3}$, respectively. These values are comparable to previous measurements during the SMOCC-2002 campaign at the pasture site mentioned above and by aircraft over smoke-impacted areas in Rondônia (Rissler et al., 2006; Chand et al., 2006). The high number concentration variability reflects the diversity of BB plume ages and dilution levels reaching the site.

Figure 9 shows the average size distribution with gaussian fits for nucleation, Aitken, and accumulation modes, as well as average size distributions observed for a given $\mathrm{O}: \mathrm{C}$ ratio. Despite a strong change in the $\mathrm{O}: \mathrm{C}$ ratio and overall aerosol number concentration, decreasing from $20000 \mathrm{~cm}^{-3}$ $(0.2<\mathrm{O}: \mathrm{C}<0.3)$ to $3900 \mathrm{~cm}^{-3}(0.6<\mathrm{O}: \mathrm{C}<0.7)$, the size distributions depict either a single accumulation mode or a superposition of Aitken and accumulation modes. Similar types of aerosol size distributions have also been observed at a forest site in the central Amazon during the dry season under the influence of aged biomass burning plumes (Artaxo et al., 2013). The measurements from BB-dominated periods during two previous campaigns in the Amazon, SMOCC2002 (Rissler et al., 2006) and CLAIRE-2001 (Rissler et al., 2004) also showed similar size distributions. In the latter study, the geometric mean diameters of the Aitken and accumulation modes were around 70 and $140 \mathrm{~nm}$, respectively, slightly smaller than the values of 98 and $179 \mathrm{~nm}$ observed here. The parameters retrieved from a Gaussian fit for each mode of the campaign-averaged size distribution are given in Table 2.

\subsection{PMF analysis}

The number of PMF factors was selected based on the total sum of squares of the scaled residuals, the analysis of temporal series of the different factors with gas-phase and $\mathrm{BC}_{\mathrm{e}}$ data, diurnal cycles, and the mass spectra. Details of the PMF analysis procedure is given in the Supplement. Three factors were identified: fresh biomass burning organic aerosol (fresh $\mathrm{BBOA}$ ), aged BBOA, and low-volatility oxygenated organic aerosol (LV-OOA). The mass spectra of the three factors are depicted in Fig. 10 and the mass contribution time series of the factors in Fig. 11. The enhancement of the fresh BBOA factor, and to some extent the aged BBOA factor, correlates well with aerosol loading peaks, whereas LV-OOA presents persistent regional pollution behavior.

Table 3 presents a correlation analysis of the factors obtained from the PMF of the ground-based data with the AMS spectra database (Ulbrich et al., 2009, 2013), the SAMBBA airborne AMS sampling biomass burning plumes in Rondônia from flight B737 (see Supplement), and the time series correlation of $\mathrm{CO}, \mathrm{BC}_{\mathrm{e}}$, sulfate, and nitrate. The fresh BBOA factor spectrum correlates well with the AMS measurements directly above ( $900 \mathrm{~m}$ altitude) a large fire in Rondônia (Pearson $=0.96$ ) as well as $1 \mathrm{~h}$ downwind of the
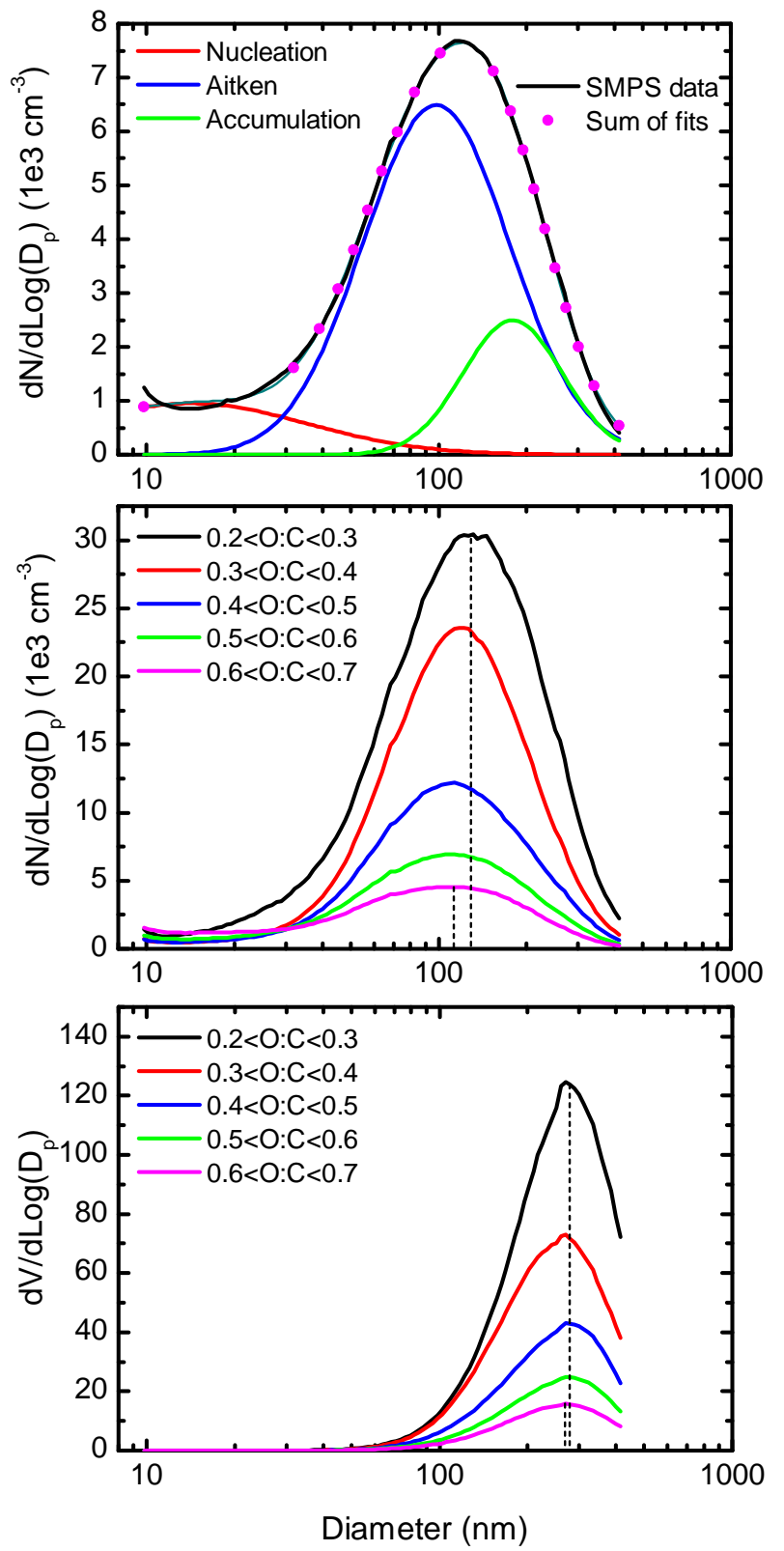

Figure 9. Top: average aerosol size distribution observed at ground level during SAMBBA. The average particle number concentration and diameter were $5800 \mathrm{~cm}^{-3}$ and $94.4 \mathrm{~nm}$, respectively. Lognormal fit parameters are shown in Table 2. Middle: solid lines show the average number size distribution based on different $\mathrm{O}$ : $\mathrm{C}$ ranges. The dashed lines indicate size distribution centroid for fresh $(130 \mathrm{~nm})$ and aged aerosol $(110 \mathrm{~nm})$. Bottom: solid lines show the average volume size distribution based on different $\mathrm{O}: \mathrm{C}$ ranges. The dashed lines indicate size distribution centroid for fresh $(278 \mathrm{~nm})$ and aged aerosol $(267 \mathrm{~nm})$.

fire $($ Pearson $=0.94)$. The correlation decreases somewhat for the airborne measurements and moderately $(3 \mathrm{~h})$ downwind $($ Pearson $=0.74)$. In contrast, aged BBOA correlates poorly with the spectrum obtained directly above the fire 
Table 3. Correlation analysis of the OA factors relative to their spectra and time series. Airborne AMS refers to the aircraft component of SAMBBA (see Supplement).

\begin{tabular}{|c|c|c|c|c|}
\hline & \multirow{2}{*}{$\begin{array}{l}\text { Reference spectrum/ } \\
\text { Specie }\end{array}$} & \multicolumn{3}{|c|}{ Pearson correlation } \\
\hline & & Fresh BBOA & Aged BBOA & LV-OOA \\
\hline \multirow[t]{3}{*}{ Airborne AMS (flight B737) } & $900 \mathrm{~m}$ above a fire & 0.96 & 0.55 & 0.37 \\
\hline & $1 \mathrm{~h}$ downwind & 0.94 & 0.73 & 0.59 \\
\hline & $3 \mathrm{~h}$ downwind & 0.74 & 0.86 & 0.80 \\
\hline \multirow[t]{5}{*}{ AMS database } & LV-OOA (Ng et al., 2011a) & 0.56 & 0.97 & 0.98 \\
\hline & SV-OOA (Ng et al., 2011a) & 0.86 & 0.83 & 0.66 \\
\hline & OOA (Ng et al., 2011a) & 0.60 & 0.98 & 0.97 \\
\hline & BBOA (Ng et al., 2011a) & 0.98 & 0.72 & 0.58 \\
\hline & HOA (Ng et al., 2011a) & 0.76 & 0.44 & 0.23 \\
\hline \multirow[t]{4}{*}{ Time series } & $\mathrm{CO}(\mathrm{ppmv})$ & 0.90 & 0.51 & 0.53 \\
\hline & Nitrate $\left(\mu \mathrm{g} \mathrm{m}^{-3}\right)$ & 0.86 & 0.61 & 0.56 \\
\hline & Sulfate $\left(\mu \mathrm{g} \mathrm{m}^{-3}\right)$ & 0.50 & 0.63 & 0.51 \\
\hline & $\mathrm{BC}_{\mathrm{e}}\left(\mu \mathrm{g} \mathrm{m}^{-3}\right)$ & 0.68 & 0.66 & 0.40 \\
\hline
\end{tabular}

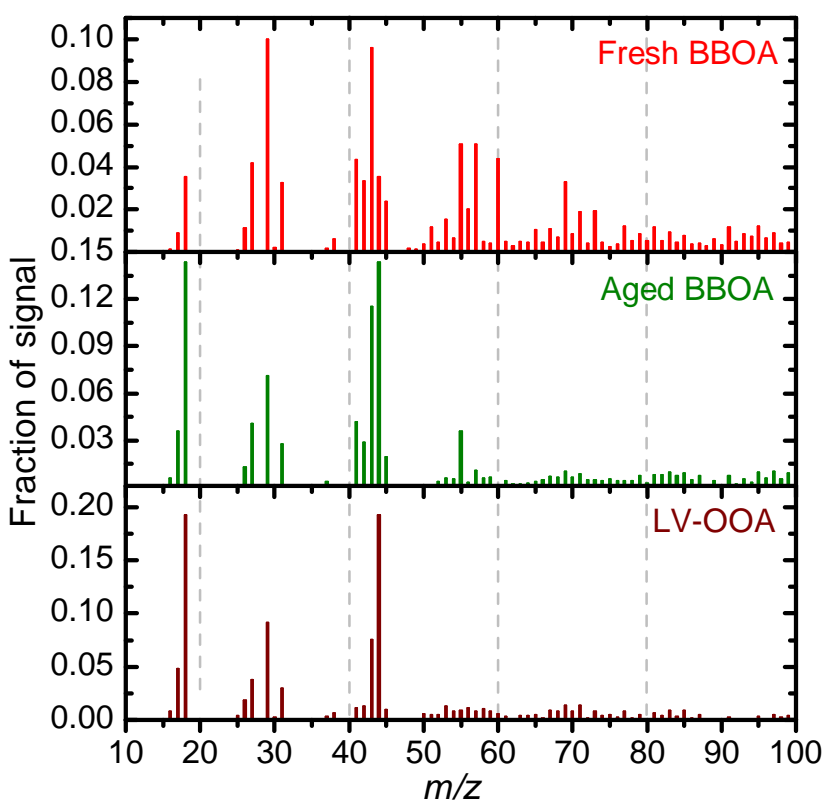

Figure 10. Mass spectra in fraction of signal of PMF factors, fresh BBOA, aged BBOA, and LV-OOA.

$($ Pearson $=0.55)$, and much better with the $3 \mathrm{~h}$ downwind spectrum (Pearson $=0.86$ ), indicating that this factor would represent $\mathrm{BB}$ aerosol processed only for a time longer than $3 \mathrm{~h}$. Similarly, the correlation of LV-OOA with the airborne AMS data improves with increasing plume processing time. The fact that LV-OOA correlates only moderately well with the OA spectrum obtained $3 \mathrm{~h}$ downwind of the fire (Pearson $=0.80$ ) suggests that the BBOA shows a LV-OOA chemical signature somewhat more slowly than an aged BBOA signature.
Comparison with the AMS mass spectra database shows that the fresh BBOA factor correlates extremely well with the database BBOA (Pearson = 0.98), whereas aged BBOA correlates with database OOA (Pearson $=0.98)$, as well as with database LV-OOA (Pearson = 0.97). Similarly, the LV-OOA factor correlates extremely well with the database LV-OOA and database OOA (Pearson $=0.98$ and 0.97, respectively).

The CO time series yields a high correlation coefficient with the fresh BBOA factor (Pearson $=0.90$ ), as both signals are related to strong biomass burning events. Whereas nitrate correlates well with fresh BBOA, indicating that biomass burning is the dominant source of this species, sulfate does not yield a high correlation with any of the resolved factors. Similarly, $\mathrm{BC}_{\mathrm{e}}$ correlates only moderately well with the BBOA factors, indicating that other sources, e.g., brickyards, might play an important role controlling its atmospheric concentration at the sampling site (see Supplement).

Figure 12 depicts the diurnal variation of the mass contribution of each factor, split into Phase I (13 to 22 September 2012) and Phase II (22 to 30 September 2012). During Phase I, the fresh and aged BBOA factors present a diurnal variation with higher concentrations during nighttime. This behavior is associated with a boundary layer height decrease during nighttime trapping freshly emitted smoke plumes. Conversely, the LV-OOA factor is enhanced considerably in the mid-afternoon along with $\mathrm{O}_{3}$ concentrations (not shown here) suggesting that it is partially driven by an active photochemistry, despite the lack of observation of an intermediate factor, such as semi-volatile OOA (Jimenez et al., 2009).

During Phase II, with increased precipitation in the study region, both BBOA factors have much lower ambient concentrations than during Phase I. Furthermore, the aged BBOA and LV-OOA factors show a different diurnal pattern from that observed during Phase I, indicating a clear 


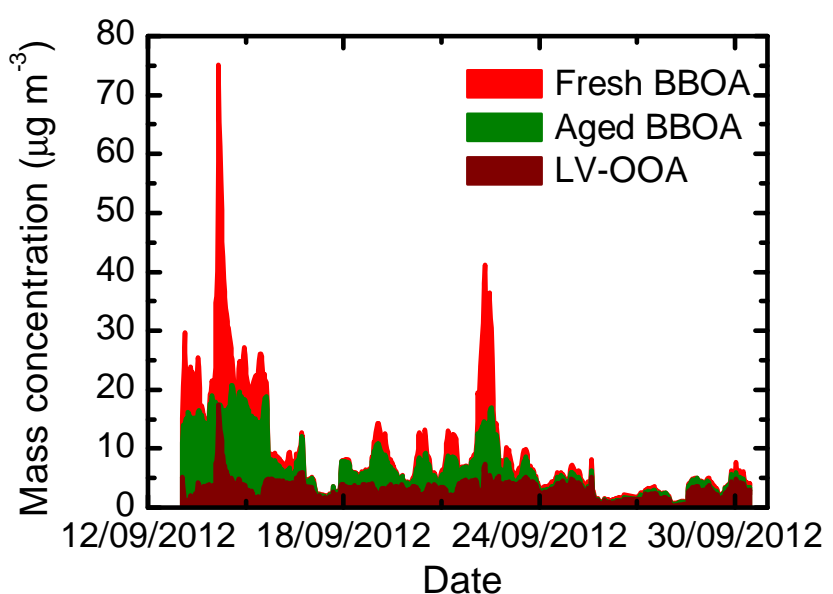

Figure 11. Organic aerosol loading time series with color-coded contributions of identified PMF factors.

loading enhancement during the first morning hours, consistent with entrainment from aloft into the near-surface layer as the boundary layer grows.

The relatively high loadings of the LV-OOA during Phase II, as well as its temporal correlation with the aged BBOA factor, suggests that an important component of this factor originates from highly processed biomass burning smoke transported aloft. Whereas the LV-OOA factor certainly encompasses highly processed pollution, it can not be excluded that it might also contain other sorts of chemically similar organic aerosols subsiding to near-surface levels. These may include, for example, the secondary aerosols previously observed to form at $2-4 \mathrm{~km}$ altitude in the northern Amazon (Krejci et al., 2003, 2005; Ekman et al., 2008). The potential contribution of other sources to the LV-OOA factor, which strongly dominates the aerosol concentration during the onset of the wet season in Rondônia, remains unclear and demands further studies.

\section{Conclusions}

We have characterized the physical and chemical properties of aerosols at a site heavily impacted by biomass burning in the southwest Brazilian Amazon during the SAMBBA field experiment. The sampling site is located $5 \mathrm{~km}$ north, and usually upwind, of the city of Porto Velho, Rondônia. The data reported here focus on the period from 13 to 30 September 2012, comprising the transition period from the dry to the wet season.

During most of the campaign, the site was impacted by regional biomass burning pollution (average $\mathrm{CO}$ mixing ratio of $0.6 \mathrm{ppm}$ ), occasionally superimposed with intense biomass burning plumes (up to $2 \mathrm{ppm}$ of $\mathrm{CO}$ ). Realtime chemical characterization has shown that organic aerosol strongly dominated the submicron non-refractory composition, with an average concentration of $11.4 \mu \mathrm{g} \mathrm{m}^{-3}$. The in-

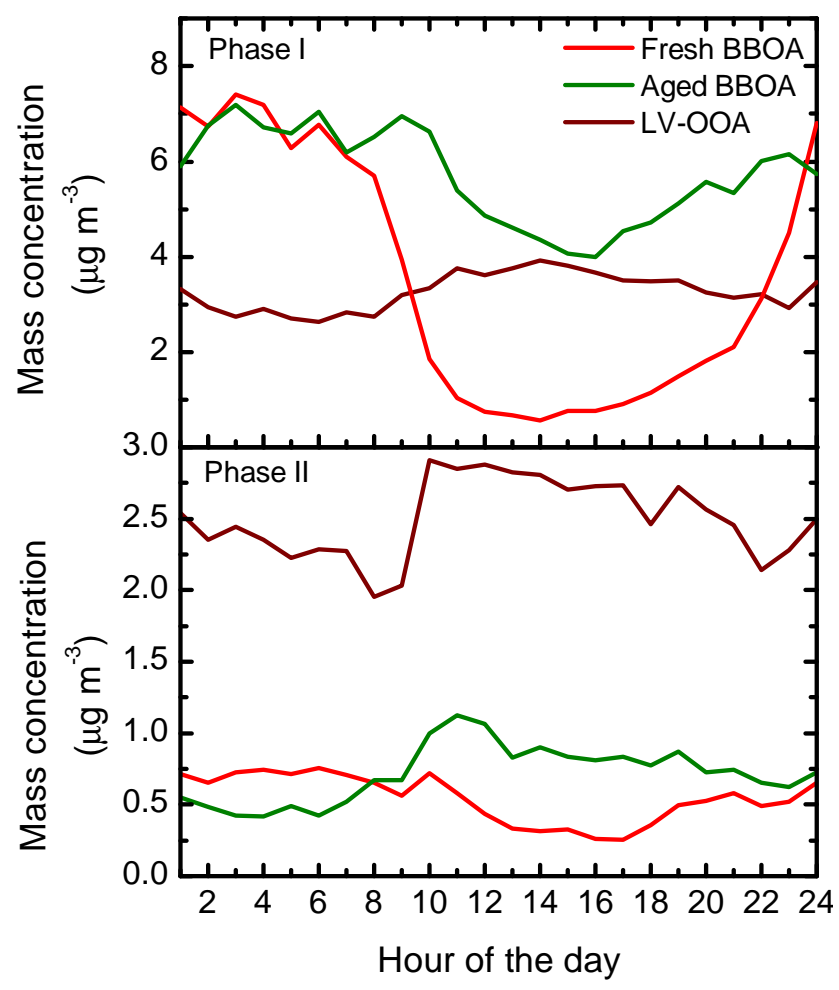

Figure 12. Diurnal variation of the three factors identified through PMF: fresh BBOA, aged BBOA, and LV-OOA. Phase I refers to the period between 13 to 22 September 2012 and Phase II from 22 to 30 September 2012.

organic species, $\mathrm{NH}_{4}, \mathrm{SO}_{4}, \mathrm{NO}_{3}$, and $\mathrm{Cl}$, were observed with concentrations of $0.44 \mu \mathrm{g} \mathrm{m}^{-3}, 0.34 \mu \mathrm{g} \mathrm{m}^{-3}, 0.19 \mu \mathrm{g} \mathrm{m}^{-3}$, and $0.01 \mu \mathrm{g} \mathrm{m}^{-3}$, respectively. Our results indicate that during strong impact of fresh biomass burning $\left(f_{60}>0.015\right)$, the fraction of organics relative to the other species measured by the ACSM plus $\mathrm{BC}_{\mathrm{e}}$ was above 0.9 , a value considerably higher than previous measurements at other locations.

The aerosol number size distributions showed a pronounced accumulation mode (with a peak at $118 \mathrm{~nm}$ and a geometric mean diameter of $94 \mathrm{~nm}$ ) and the average particle number was $5700 \mathrm{~cm}^{-3}$. The average aerosol size distribution was studied as a function of the $\mathrm{O}: \mathrm{C}$ ratio, a surrogate for atmospheric processing. Despite a strong change in the $\mathrm{O}: \mathrm{C}$ ratio and the overall aerosol number concentration as a function of ageing, decreasing from $20000 \mathrm{~cm}^{-3}$ $(0.2<\mathrm{O}: \mathrm{C}<0.3)$ down to $3900 \mathrm{~cm}^{-3}(0.6<\mathrm{O}: \mathrm{C}<0.7)$, the size distributions did not change much. They can be represented by either a single accumulation mode or a superposition of Aitken and accumulation modes.

Chemical processing during aerosol ageing has been studied as well using a VK diagram, i.e., a plot of the $\mathrm{O}: \mathrm{C}$ vs. the $\mathrm{H}: \mathrm{C}$ ratio. During the peak of a fresh $\mathrm{BB}$ plume event $\left(f_{60}>0.03\right)$, we observed $\mathrm{H}: \mathrm{C}=1.35$ and $\mathrm{O}: \mathrm{C}=0.25$, which is a relatively lower $\mathrm{H}: \mathrm{C}$ ratio than has been previously reported for Amazonian biogenic aerosols $(\mathrm{H}: \mathrm{C}=1.6$ 
and $\mathrm{O}: \mathrm{C}=0.2$ ). As the BBOA is processed, the $\mathrm{H}: \mathrm{C}$ and $\mathrm{O}: \mathrm{C}$ ratios move towards values closer to previous measurements that had been made under strong biogenic influences. This is probably due to both a chemical convergence in the course of ageing and an increasing contribution of biogenic aerosols in older air masses. Whereas biogenic organic aerosols have been shown to follow a clear processing path along a line with a slope of -1 in the VK diagram, the OA observed here shows a different behavior, where the majority of aerosol processing (from $\mathrm{O}: \mathrm{C} \cong 0.25$ to $\mathrm{O}: \mathrm{C} \cong 0.6$ ) is accompanied by only a small change in the $\mathrm{H}: \mathrm{C}$ ratio. Such processing is consistent with the replacement of a hydrogen with an alcohol group (-OH), for example. For $\mathrm{O}: \mathrm{C}>0.6$, the average slope changes to -0.5 . Such a slope could arise from an increase in the contribution of biogenic aerosol processing (slope $=-1$ ) together with BBOA processing (slope $=0$ ), and/or a change in the reaction mechanisms. In case of the latter, it could represent the replacement of a $-\mathrm{CH}_{2}$ group with a $-\mathrm{COOH}$ group due to the addition of a carboxylic acid group to the site of a $\mathrm{C}-\mathrm{C}$ bond cleavage. Another possibility, expected under low- $\mathrm{NO}_{\mathrm{x}}$ conditions, would arise from formation of peroxides through the addition of one $\mathrm{OOH}$ group, one $\mathrm{OH}$ group, and one $\mathrm{C}=\mathrm{O}$ group, or the addition of one $\mathrm{OOH}$ group and one $\mathrm{COOH}$ group. The impact of plume ageing on SOA production was also investigated. Our results indicate no observable net OA production with atmospheric processing at the SAMBBA ground site.

Positive matrix factorization of the organic aerosol spectra yielded three factors: fresh BBOA, aged BBOA, and LV-OOA. The enhancement of the fresh BBOA factor, and to some extent the aged BBOA factor, correlates well with peaks in aerosol loading, whereas LV-OOA suggests a persistent regional background. The $\mathrm{CO}$ time series shows a high correlation with the fresh BBOA factor (Pearson $=0.90$ ) as both signals are related to strong biomass burning events. The nitrate concentration yields a high correlation with fresh BBOA factor as well, thus showing that biomass burning events are the dominant source of this specie. Unlike $\mathrm{CO}$, sulfate and $\mathrm{BC}_{\mathrm{e}}$ correlate only moderately well with $\mathrm{BBOA}$ factors, indicating that other sources might play an important role controlling their atmospheric concentration at the sampling site. Analysis of the diurnal patterns and correlation with external markers indicate that during the first part of the campaign, the OA concentrations are strongly dominated by nearby fire plumes, with chemical processing occurring in the near-surface boundary layer. During the second part of the campaign, long-range transport of $\mathrm{BB}$ plumes above the boundary layer has a strong influence on the OA concentrations at our ground-based sampling site.

\section{The Supplement related to this article is available online at doi:10.5194/acp-14-12069-2014-supplement.}

Acknowledgements. This work was supported by the Foundation for Research Support of the State of São Paulo (FAPESP, projects 2012/14437-9 and 2013/05014-0), CNPq project 4757352012-9, INCT Amazonia, and Natural Environment Research Council (NERC) project NE/J010073/1. We thank A. Ribeiro, A. L. Loureiro, F. Morais, F. Jorge, and S. Morais for technical and logistics support. We thank the National Institute of Meteorology for providing valuable meteorological data. We gratefully acknowledge S. Hacon, J. Silva, and W. Bastos for support in the successful operation of the sampling site.

Edited by: G. Myhre

\section{References}

Aiken, A. C., Decarlo, P. F., Kroll, J. H., Worsnop, D. R., Huffman, J. A., Docherty, K. S., Ulbrich, I. M., Mohr, C., Kimmel, J. R., Sueper, D., Sun, Y., Zhang, Q., Trimborn, A., Northway, M., Ziemann, P. J., Canagaratna, M. R., Onasch, T. B., Alfarra, M. R., Prevot, A. S. H., Dommen, J., Duplissy, J., Metzger, A., Baltensperger, U., and Jimenez, J. L.: O/C and OM/OC ratios of primary, secondary, and ambient organic aerosols with high-resolution time-of-flight aerosol mass spectrometry, Environ. Sci. Technol., 42, 4478-85, 2008.

Aiken, A. C., de Foy, B., Wiedinmyer, C., DeCarlo, P. F., U1brich, I. M., Wehrli, M. N., Szidat, S., Prevot, A. S. H., Noda, J., Wacker, L., Volkamer, R., Fortner, E., Wang, J., Laskin, A., Shutthanandan, V., Zheng, J., Zhang, R., ParedesMiranda, G., Arnott, W. P., Molina, L. T., Sosa, G., Querol, X., and Jimenez, J. L.: Mexico city aerosol analysis during MILAGRO using high resolution aerosol mass spectrometry at the urban supersite (T0) - Part 2: Analysis of the biomass burning contribution and the non-fossil carbon fraction, Atmos. Chem. Phys., 10, 5315-5341, doi:10.5194/acp-10-5315-2010, 2010.

Akagi, S. K., Craven, J. S., Taylor, J. W., McMeeking, G. R., Yokelson, R. J., Burling, I. R., Urbanski, S. P., Wold, C. E., Seinfeld, J. H., Coe, H., Alvarado, M. J., and Weise, D. R.: Evolution of trace gases and particles emitted by a chaparral fire in California, Atmos. Chem. Phys., 12, 1397-1421, doi:10.5194/acp-121397-2012, 2012.

Alfarra, M. R., Prevot, A. S. H., Szidat, S., Sandradewi, J., Weimer, S., Lanz, V. A., Schreiber, D., Mohr, M., and Baltensperger, U.: Identification of the mass spectral signature of organic aerosols from wood burning emissions, Environ. Sci. Technol., 41, 5770-5777, doi:10.1021/es062289b, 2007.

Allan, J. D., Delia, A. E., Coe, H., Bower, K. N., Alfarra, M., Jimenez, J. L., Middlebrook, A. M., Drewnick, F., Onasch, T. B., Canagaratna, M. R., Jayne, J. T., and Worsnop, D. R.: A generalised method for the extraction of chemically resolved mass spectra from Aerodyne aerosol mass spectrometer data, J. Aerosol Sci., 35, 909-922, 2004.

Andreae, M. O.: Aerosols before pollution, Science, 315, 50-51, doi:10.1126/science.1136529, 2007.

Andreae, M. O., Artaxo, P., Fischer, H., Freitas, S. R., Gregoire, J.-M., Hansel, A., Hoor, P., Kormann, R., Krejci, R., Lange, L., Lelieveld, J., Lindinger, W., Longo, K., Peters, W., de Reus, M., Scheeren, B., Silva Dias, M. A. F., Strom, J., van Velthoven, P. F. J., and Williams, J.: Transport of biomass 
burning smoke to the upper troposphere by deep convection in the equatorial region, Geophys. Res. Lett., 28, 951-954, doi:10.1029/2000GL012391, 2001.

Andreae, M. O., Rosenfeld, D., Artaxo, P., Costa, A. A., Frank, G. P., Longo, K. M., and Silva-Dias, M. A. F.: Smoking rain clouds over the Amazon, Science, 303, 1337-1342, doi:10.1126/science.1092779, 2004.

Andreae, M. O., Artaxo, P., Beck, V., Bela, M., Freitas, S., Gerbig, C., Longo, K., Munger, J. W., Wiedemann, K. T., and Wofsy, S. C.: Carbon monoxide and related trace gases and aerosols over the Amazon Basin during the wet and dry seasons, Atmos. Chem. Phys., 12, 6041-6065, doi:10.5194/acp-12-60412012, 2012.

Arnott, W. P., Hamasha, K., Moosmüller, H., Sheridan, P. J., and Ogren, J. A.: Towards aerosol light-absorption measurements with a 7-wavelength aethalometer: evaluation with a photoacoustic instrument and 3-wavelength nephelometer, Aerosol Sci. Tech., 39, 17-29, doi:10.1080/027868290901972, 2005.

Artaxo, P., Storms, H., Bruynseels, F., Van Grieken, R., and Maenhaut, W.: Composition and sources of aerosols from the Amazon Basin, J. Geophys. Res.-Atmos., 93, 1605-1615, doi:10.1029/JD093iD02p01605, 1988.

Artaxo, P., Martins, J. V., Yamasoe, M. A., Procopio, A. S., Pauliquevis, T. M., Andreae, M. O., Guyon, P., Gatti, L. V., and Leal, A. M. C.: Physical and chemical properties of aerosols in the wet and dry seasons in Rondonia, Amazonia, J. Geophys. Res.-Atmos., 107, LBA 49-1-LBA 49-14, doi:10.1029/2001JD000666, 2002.

Artaxo, P., Rizzo, L. V., Brito, J. F., Barbosa, H. M. J., Arana, A., Sena, E. T., Cirino, G. G., Bastos, W., Martin, S. T., and Andreae, M. O.: Atmospheric aerosols in Amazonia and land use change: from natural biogenic to biomass burning conditions, Faraday Discuss., 165, 203-235, doi:10.1039/C3FD00052D, 2013

Bae, M.-S., Schwab, J. J., Zhang, Q., Hogrefe, O., Demerjian, K. L., Weimer, S., Rhoads, K., Orsini, D., Venkatachari, P., and Hopke, P. K.: Interference of organic signals in highly time resolved nitrate measurements by low mass resolution aerosol mass spectrometry, J. Geophys. Res.-Atmos., 112, D22305, doi:10.1029/2007JD008614, 2007.

Canagaratna, M., Jayne, J., Jimenez, J., Allan, J., Alfarra, M., Zhang, Q., Onasch, T., Drewnick, F., Coe, H., Middlebrook, A., Delia, A., Williams, L., Trimborn, A., Northway, M., DeCarlo, P., Kolb, C., Davidovits, P., and Worsnop, D.: Chemical and microphysical characterization of ambient aerosols with the aerodyne aerosol mass spectrometer, Mass Spectrom. Rev., 26, 185-222, doi:10.1002/mas.20115, 2007.

Canagaratna, M. R., Jimenez, J. L., Kroll, J. H., Chen, Q., Kessler, S. H., Massoli, P., Hildebrandt Ruiz, L., Fortner, E., Williams, L. R., Wilson, K. R., Surratt, J. D., Donahue, N. M., Jayne, J. T. and Worsnop, D. R.: Elemental ratio measurements of organic compounds using aerosol mass spectrometry: characterization, improved calibration, and implications, Atmos. Chem. Phys. Discuss., 14, 19791-019835, doi::10.5194/acpd-14-197912014, 2014.

Capes, G., Johnson, B., McFiggans, G., Williams, P. I., Haywood, J., and Coe, H.: Aging of biomass burning aerosols over West Africa: Aircraft measurements of chemical composition, microphysical properties, and emission ratios, J. Geophys. Res.Atmos., 113, D00C15, doi:10.1029/2008JD009845, 2008.

Carbone, S., Saarikoski, S., Frey, A., Reyes, F., Reyes, P., Castillo, M., Gramsch, E., Oyola, P., Jayne, J., Worsnop, D. R., and Hillamo, R.: Chemical characterization of submicron aerosol particles in Santiago de Chile, Aerosol Air Qual. Res., 13, 462-473, doi:10.4209/aaqr.2012.10.0261, 2013.

Chand, D., Guyon, P., Artaxo, P., Schmid, O., Frank, G. P., Rizzo, L. V., Mayol-Bracero, O. L., Gatti, L. V., and Andreae, M. O.: Optical and physical properties of aerosols in the boundary layer and free troposphere over the Amazon Basin during the biomass burning season, Atmos. Chem. Phys., 6, 2911-2925, doi:10.5194/acp-6-2911-2006, 2006.

Chen, Q., Farmer, D. K., Schneider, J., Zorn, S. R., Heald, C. L., Karl, T. G., Guenther, A., Allan, J. D., Robinson, N., Coe, H., Kimmel, J. R., Pauliquevis, T., Borrmann, S., Pöschl, U., Andreae, M. O., Artaxo, P., Jimenez, J. L., and Martin, S. T.: Mass spectral characterization of submicron biogenic organic particles in the Amazon Basin, Geophys. Res. Lett., 36, L20806, doi:10.1029/2009GL039880, 2009.

Cubison, M. J., Ortega, A. M., Hayes, P. L., Farmer, D. K., Day, D., Lechner, M. J., Brune, W. H., Apel, E., Diskin, G. S., Fisher, J. A., Fuelberg, H. E., Hecobian, A., Knapp, D. J., Mikoviny, T., Riemer, D., Sachse, G. W., Sessions, W., Weber, R. J., Weinheimer, A. J., Wisthaler, A., and Jimenez, J. L.: Effects of aging on organic aerosol from open biomass burning smoke in aircraft and laboratory studies, Atmos. Chem. Phys., 11, 12049-12064, doi:10.5194/acp-11-12049-2011, 2011.

Davidson, E. A., de Araújo, A. C., Artaxo, P., Balch, J. K., Brown, I. F., Bustamante, M. M. C., Coe, M. T., DeFries, R. S., Keller, M., Longo, M., Munger, J. W., Schroeder, W., SoaresFilho, B. S., Souza, C. M., and Wofsy, S. C.: The Amazon basin in transition, Nature, 481, 321-328, doi:10.1038/nature10717, 2012.

De Gouw, J. and Jimenez, J. L.: Organic aerosols in the Earth's atmosphere, Environ. Sci. Technol., 43, 7614-7618, doi:10.1021/es9006004, 2009.

DeCarlo, P. F., Dunlea, E. J., Kimmel, J. R., Aiken, A. C., Sueper, D., Crounse, J., Wennberg, P. O., Emmons, L., Shinozuka, Y., Clarke, A., Zhou, J., Tomlinson, J., Collins, D. R., Knapp, D., Weinheimer, A. J., Montzka, D. D., Campos, T., and Jimenez, J. L.: Fast airborne aerosol size and chemistry measurements above Mexico City and Central Mexico during the MILAGRO campaign, Atmos. Chem. Phys., 8, 4027-4048, doi:10.5194/acp-8-4027-2008, 2008.

DeCarlo, P. F., Ulbrich, I. M., Crounse, J., de Foy, B., Dunlea, E. J., Aiken, A. C., Knapp, D., Weinheimer, A. J., Campos, T., Wennberg, P. O., and Jimenez, J. L.: Investigation of the sources and processing of organic aerosol over the Central Mexican Plateau from aircraft measurements during MILAGRO, Atmos. Chem. Phys., 10, 5257-5280, doi:10.5194/acp-10-52572010, 2010.

Doughty, C. E., Flanner, M. G., and Goulden, M. L.: Effect of smoke on subcanopy shaded light, canopy temperature, and carbon dioxide uptake in an Amazon rainforest, Global Biogeochem. Cy., 24, GB3015, doi:10.1029/2009GB003670, 2010.

Ekman, A. M. L., Krejci, R., Engström, A., Ström, J., de Reus, M., Williams, J., and Andreae, M. O.: Do organics contribute to small 
particle formation in the Amazonian upper troposphere?, Geophys. Res. Lett., 35, L17810, doi:10.1029/2008GL034970, 2008.

Feingold, G., Jiang, H., and Harrington, J. Y.: On smoke suppression of clouds in Amazonia, Geophys. Res. Lett., 32, L02804, doi:10.1029/2004GL021369, 2005.

Freitas, S., Longo, K., Silva Dias, M., Silva Dias, P., Chatfield, R., Prins, E., Artaxo, P., Grell, G., and Recuero, F.: Monitoring the transport of biomass burning emissions in South America, Environ. Fluid Mech., 5, 135-167, doi:10.1007/s10652-005-0243-7, 2005.

Heald, C. L., Kroll, J. H., Jimenez, J. L., Docherty, K. S., DeCarlo, P. F., Aiken, A. C., Chen, Q., Martin, S. T., Farmer, D. K., and Artaxo, P.: A simplified description of the evolution of organic aerosol composition in the atmosphere, Geophys. Res. Lett., 37, L08803, doi:10.1029/2010GL042737, 2010.

Huffman, J. A., Jayne, J. T., Drewnick, F., Aiken, A. C., Onasch, T., Worsnop, D. R., and Jimenez, J. L.: Design, modeling, optimization, and experimental tests of a particle beam width probe for the Aerodyne aerosol mass spectrometer, Aerosol Sci. Tech., 39, 1143-1163, doi:10.1080/02786820500423782, 2005.

Hussein, T., Dal Maso, M., Petaja, T., Koponen, I. K., Paatero, P., Aalto, P. P., Hameri, K., and Kulmala, M.: Evaluation of an automatic algorithm for fitting the particle number size distributions, Boreal Environ. Res., 10, 337-355, 2005.

Jayne, J. T., Leard, D. C., Zhang, X., Davidovits, P., Smith, K. A., Kolb, C. E., and Worsnop, D. R.: Development of an aerosol mass spectrometer for size and composition analysis of submicron particles, Aerosol Sci. Tech., 33, 49-70, doi:10.1080/027868200410840, 2000.

Jimenez, J. L., Canagaratna, M. R., Donahue, N. M., Prevot, A. S. H., Zhang, Q., Kroll, J. H., DeCarlo, P. F., Allan, J. D., Coe, H., Ng, N. L., Aiken, A. C., Docherty, K. S., Ulbrich, I. M., Grieshop, A. P., Robinson, A. L., Duplissy, J., Smith, J. D., Wilson, K. R., Lanz, V. A., Hueglin, C., Sun, Y. L., Tian, J., Laaksonen, A., Raatikainen, T., Rautiainen, J., Vaattovaara, P., Ehn, M., Kulmala, M., Tomlinson, J. M., Collins, D. R., Cubison, M. J., E., Dunlea, J., Huffman, J. A., Onasch, T. B., Alfarra, M. R., Williams, P. I., Bower, K., Kondo, Y., Schneider, J., Drewnick, F., Borrmann, S., Weimer, S., Demerjian, K., Salcedo, D., Cottrell, L., Griffin, R., Takami, A., Miyoshi, T., Hatakeyama, S., Shimono, A., Sun, J. Y., Zhang, Y. M., Dzepina, K., Kimmel, J. R., Sueper, D., Jayne, J. T., Herndon, S. C., Trimborn, A. M., Williams, L. R., Wood, E. C., Middlebrook, A. M., Kolb, C. E., Baltensperger, U., and Worsnop, D. R.: Evolution of organic aerosols in the atmosphere, Science, 326, 1525-1529, doi:10.1126/science.1180353, 2009.

Jolleys, M. D., Coe, H., McFiggans, G., Capes, G., Allan, J. D., Crosier, J., Williams, P. I., Allen, G., Bower, K. N., Jimenez, J. L., Russell, L. M., Grutter, M., and Baumgardner, D.: Characterizing the aging of biomass burning organic aerosol by use of mixing ratios: a meta-analysis of four regions, Environ. Sci. Technol., 46, 13093-13102, doi:10.1021/es302386v, 2012.

Koren, I., Kaufman, Y. J., Remer, L. A., and Martins, J. V.: Measurement of the effect of Amazon smoke on inhibition of cloud formation, Science, 303, 1342-1345, doi:10.1126/science.1089424, 2004.

Koren, I., Kaufman, Y. J., Rosenfeld, D., Remer, L. A., and Rudich, Y: Aerosol invigoration and restructuring of At- lantic convective clouds, Geophys. Res. Lett., 32, L14828, doi:10.1029/2005GL023187, 2005.

Krejci, R., Ström, J., de Reus, M., Hoor, P., Williams, J., Fischer, H., and Hansson, H.-C.: Evolution of aerosol properties over the rain forest in Surinam, South America, observed from aircraft during the LBA-CLAIRE 98 experiment, J. Geophys. Res.-Atmos., 108, 4561, doi:10.1029/2001JD001375, 2003.

Krejci, R., Ström, J., de Reus, M., Williams, J., Fischer, H., Andreae, M. O., and Hansson, H.-C.: Spatial and temporal distribution of atmospheric aerosols in the lowermost troposphere over the Amazonian tropical rainforest, Atmos. Chem. Phys., 5, 1527-1543, doi:10.5194/acp-5-1527-2005, 2005.

Kuwata, M., Zorn, S. R. and Martin, S. T.: Using elemental ratios to predict the density of organic material composed of carbon, hydrogen, and oxygen., Environ. Sci. Technol., 46, 787-794, doi:10.1021/es202525q, 2012.

Lack, D. A., Bahreini, R., Langridge, J. M., Gilman, J. B., and Middlebrook, A. M.: Brown carbon absorption linked to organic mass tracers in biomass burning particles, Atmos. Chem. Phys., 13, 2415-2422, doi:10.5194/acp-13-2415-2013, 2013.

Lanz, V. A., Alfarra, M. R., Baltensperger, U., Buchmann, B., Hueglin, C., and Prévôt, A. S. H.: Source apportionment of submicron organic aerosols at an urban site by factor analytical modelling of aerosol mass spectra, Atmos. Chem. Phys., 7, 1503-1522, doi:10.5194/acp-7-1503-2007, 2007.

Lide, D. R.: CRC Handbook of Chemistry and Physics, CRC Press Inc, USA, 1991.

Lin, J. C., Matsui, T., Pielke, R. A., and Kummerow, C.: Effects of biomass-burning-derived aerosols on precipitation and clouds in the Amazon Basin: a satellite-based empirical study, J. Geophys Res.-Atmos., 111, D19204, doi:10.1029/2005JD006884, 2006.

Malhi, Y., Roberts, J. T., Betts, R. A., Killeen, T. J., Li, W., and Nobre, C. A.: Climate change, deforestation, and the fate of the Amazon, Science, 319, 169-172, doi:10.1126/science.1146961, 2008.

Matthew, B. M., Middlebrook, A. M., and Onasch, T. B.: Collection efficiencies in an Aerodyne aerosol mass spectrometer as a function of particle phase for laboratory generated aerosols, Aerosol Sci. Tech., 42, 884-898, doi:10.1080/02786820802356797, 2008.

Mercado, L. M., Bellouin, N., Sitch, S., Boucher, O., Huntingford, C., Wild, M., and Cox, P. M.: Impact of changes in diffuse radiation on the global land carbon sink, Nature, 458, 1014-1017, doi:10.1038/nature07949, 2009.

Middlebrook, A. M., Bahreini, R., Jimenez, J. L., and Canagaratna, M. R.: Evaluation of composition-dependent collection efficiencies for the Aerodyne aerosol mass spectrometer using field data, Aerosol Sci. Tech., 46, 258-271, doi:10.1080/02786826.2011.620041, 2012.

Morgan, W. T., Allan, J. D., Bower, K. N., Highwood, E. J., Liu, D., McMeeking, G. R., Northway, M. J., Williams, P. I., Krejci, R., and Coe, H.: Airborne measurements of the spatial distribution of aerosol chemical composition across Europe and evolution of the organic fraction, Atmos. Chem. Phys., 10, 4065-4083, doi:10.5194/acp-10-4065-2010, 2010.

Ng, N. L., Canagaratna, M. R., Zhang, Q., Jimenez, J. L., Tian, J., Ulbrich, I. M., Kroll, J. H., Docherty, K. S., Chhabra, P. S., Bahreini, R., Murphy, S. M., Seinfeld, J. H., Hildebrandt, L., Donahue, N. M., DeCarlo, P. F., Lanz, V. A., Prévôt, A. S. H., Di- 
nar, E., Rudich, Y., and Worsnop, D. R.: Organic aerosol components observed in Northern Hemispheric datasets from Aerosol Mass Spectrometry, Atmos. Chem. Phys., 10, 4625-4641, doi:10.5194/acp-10-4625-2010, 2010.

Ng, N. L., Canagaratna, M. R., Jimenez, J. L., Chhabra, P. S., Seinfeld, J. H., and Worsnop, D. R.: Changes in organic aerosol composition with aging inferred from aerosol mass spectra, Atmos. Chem. Phys., 11, 6465-6474, doi:10.5194/acp-11-64652011, 2011a.

Ng, N. L., Herndon, S. C., Trimborn, A., Canagaratna, M. R., Croteau, P. L., Onasch, T. B., Sueper, D., Worsnop, D. R., Zhang, Q., Sun, Y. L., and Jayne, J. T.: An Aerosol Chemical Speciation Monitor (ACSM) for routine monitoring of the composition and mass concentrations of ambient aerosol, Aerosol Sci. Tech., 45, 780-794, doi:10.1080/02786826.2011.560211, 2011b.

Oliveira, P. H. F., Artaxo, P., Pires, C., De Lucca, S., Procópio, A., Holben, B., Schafer, J., Cardoso, L. F., Wofsy, S. C., and Rocha, H. R.: The effects of biomass burning aerosols and clouds on the $\mathrm{CO}_{2}$ flux in Amazonia, Tellus B, 59, 338-349, doi:10.1111/j.1600-0889.2007.00270.x, 2007.

Ometto, J. P. H., Nobre, A. D., Rocha, H. R., Artaxo, P., and Martinelli, L. A.: Amazonia and the modern carbon cycle: lessons learned, Oecologia, 143, 483-500, doi:10.1007/s00442005-0034-3, 2005.

Paatero, P.: Least squares formulation of robust non-negative factor analysis, Chemometr. Intell. Lab., 37, 23-35, 1997.

Paatero, P. and Tapper, U.: Positive matrix factorization: a nonnegative factor model with optimal utilization of error estimates of data values, Environmetrics, 5, 111-126, 1994.

Park, K., Kittelson, D. B., Zachariah, M. R. and Mcmurry, P. H.: Measurement of inherent material density of nanoparticle agglomerates, J. Nanoparticle Res., 6, 267-272, 2004.

Pöschl, U., Martin, S. T., Sinha, B., Chen, Q., Gunthe, S. S., Huffman, J. A., Borrmann, S., Farmer, D. K., Garland, R. M., Helas, G., Jimenez, J. L., King, S. M., Manzi, A., Mikhailov, E., Pauliquevis, T., Petters, M. D., Prenni, A. J., Roldin, P., Rose, D., Schneider, J., Su, H., Zorn, S. R., Artaxo, P., and Andreae, M. O.: Rainforest aerosols as biogenic nuclei of clouds and precipitation in the Amazon, Science, 329, 1513-1516, doi:10.1126/science.1191056, 2010.

Rissler, J., Swietlicki, E., Zhou, J., Roberts, G., Andreae, M. O., Gatti, L. V., and Artaxo, P.: Physical properties of the submicrometer aerosol over the Amazon rain forest during the wetto-dry season transition - comparison of modeled and measured CCN concentrations, Atmos. Chem. Phys., 4, 2119-2143, doi:10.5194/acp-4-2119-2004, 2004.
Rissler, J., Vestin, A., Swietlicki, E., Fisch, G., Zhou, J., Artaxo, P., and Andreae, M. O.: Size distribution and hygroscopic properties of aerosol particles from dry-season biomass burning in Amazonia, Atmos. Chem. Phys., 6, 471-491, doi:10.5194/acp-6-4712006, 2006.

Schmid, O., Artaxo, P., Arnott, W. P., Chand, D., Gatti, L. V., Frank, G. P., Hoffer, A., Schnaiter, M., and Andreae, M. O.: Spectral light absorption by ambient aerosols influenced by biomass burning in the Amazon Basin. I: Comparison and field calibration of absorption measurement techniques, Atmos. Chem. Phys., 6, 3443-3462, doi:10.5194/acp-6-3443-2006, 2006.

Schneider, J., Weimer, S., Drewnick, F., Borrmann, S., Helas, G., Gwaze, P., Schmid, O., Andreae, M., and Kirchner, U.: Mass spectrometric analysis and aerodynamic properties of various types of combustion-related aerosol particles, Int. J. Mass Spectrom., 258, 37-49, doi:10.1016/j.ijms.2006.07.008, 2006.

Sena, E. T., Artaxo, P., and Correia, A. L.: Spatial variability of the direct radiative forcing of biomass burning aerosols and the effects of land use change in Amazonia, Atmos. Chem. Phys., 13, 1261-1275, doi:10.5194/acp-13-1261-2013, 2013.

Ulbrich, I., Lechner, M., and Jimenez, J.: AMS Spectral Database, available at: http://cires.colorado.edu/jimenez-group/ AMSsd/ (last access: 1 October 2013), 2013.

Ulbrich, I. M., Canagaratna, M. R., Zhang, Q., Worsnop, D. R., and Jimenez, J. L.: Interpretation of organic components from Positive Matrix Factorization of aerosol mass spectrometric data, Atmos. Chem. Phys., 9, 2891-2918, doi:10.5194/acp-9-2891-2009, 2009.

Van Krevelen, D.: Graphical-statistical method for the study of structure and reaction processes of coal, Fuel, 24, 269-84, 1950.

Yamasoe, M. A., von Randow, C., Manzi, A. O., Schafer, J. S., Eck, T. F., and Holben, B. N.: Effect of smoke and clouds on the transmissivity of photosynthetically active radiation inside the canopy, Atmos. Chem. Phys., 6, 1645-1656, doi:10.5194/acp-61645-2006, 2006.

Yee, L. D., Kautzman, K. E., Loza, C. L., Schilling, K. A., Coggon, M. M., Chhabra, P. S., Chan, M. N., Chan, A. W. H., Hersey, S. P., Crounse, J. D., Wennberg, P. O., Flagan, R. C., and Seinfeld, J. H.: Secondary organic aerosol formation from biomass burning intermediates: phenol and methoxyphenols, Atmos. Chem. Phys., 13, 8019-8043, doi:10.5194/acp-13-80192013, 2013.

Zhang, Y., Fu, R., Yu, H., Qian, Y., Dickinson, R., Silva Dias, M. A. F., da Silva Dias, P. L., and Fernandes, K.: Impact of biomass burning aerosol on the monsoon circulation transition over Amazonia, Geophys. Res. Lett., 36, L10814, doi:10.1029/2009GL037180, 2009. 